\title{
Burushaski Shepherd Vocabulary of Indo-European Origin
}

\author{
Ilija Čašule \\ Macquarie University
}

\begin{abstract}
The etymological analysis of Burushaski shepherd vocabulary shows that almost all the pastoral terms in this language are of IndoEuropean origin (some thirty independently of Indic and Iranian), with a significant proportion showing close correlations with the Paleobalkanic substratal shepherd terms. Considering the conservatism of this semantic field and together with the precise, specific and systematic phonological, grammatical and lexical correspondences, this is further evidence for the Indo-European and Balkan origin of Burushaski.
\end{abstract}

Keywords: Burushaski, etymology, shepherd vocabulary, IndoEuropean, ancient Balkan languages, Albanian and Rumanian substratum.

\section{Introduction}

Burushaski, still considered a language-isolate, ${ }^{1}$ is spoken by around 90,000 people (Berger 1990: 567) in the Karakoram area in North-

1 There have been many unsuccessful attempts at correlating it with Basque, Nubian, the Dravidian languages, Munda, various Caucasic languages, 
West Pakistan at the junction of three linguistic families - the IndoEuropean (Indo-Aryan and Iranian), the Sino-Tibetan and the Turkic. Its dialectal differentiation is minor. There are three very closely related dialects: Hunza and Nager with minimal differences, and the Yasin dialect, which exhibits differential traits, but is still mutually intelligible with the former two.

The earliest sketchy descriptions and word lists of Burushaski are from the mid to late nineteenth century (e.g. Cunningham 1854; Hayward 1871; Biddulph 1880; Leitner 1889). The limited dialectal differentiation and the lack of older attestations make the internal historical reconstruction extremely difficult.

The most notable and authoritative modern description is Berger's (1998) three-volume work on the Hunza-Nager dialect. Still very relevant is Lorimer's earlier ground-breaking three-volume work on Hunza-Nager (1935-1938) and Yasin (1962) Burushaski. Edel'manKlimov's (1970) analysis (revised and summarised in Edel'man (1997) is valuable in the quality of the grammatical description. Willson's (1999) compact basic Burushaski vocabulary is also very useful. Fundamental for the study of Yasin Burushaski are Berger's (1974), Tiffou-Pesot's (1989), Tiffou-Morin's (1989) and Zarubin's (1927) works.

Berger's (2008) posthumously published synthesis is instrumental in establishing aspects of the historical phonology and morphology of Burushaski and its internal reconstruction.

In our comparative historical work (Čašule 1998, 2003a, 2003b, 2004), we have uncovered regular phonological correspondences between Burushaski and Indo-European (outside of Indic and Iranian) in over 550 lexical correspondences, largely in core vocabulary and in compact semantic fields (the correspondences [over 70 of them] in the names of body parts can be found in Čašule (2003a). Most importantly, and highly significant in determining genetic relationship, we have found very significant and fundamental derivational and 
grammatical $^{2}$ correspondences (in the personal pronouns, the whole system of demonstratives, nominal case and plural endings and derivational suffixes, the numerals, verbal prefixes, suffixes and endings, the complete non-finite verbal system, all of the adjectival suffixes, adverbs, postpositions, etc.). ${ }^{3}$ We concluded that Burushaski displays characteristics of a language which could have had an early relationship or contact in its history with the Southern (Aegean) branch of Indo-European on the one hand (see esp. Čašule [2004], on the possible correlation with Phrygian) and with the Northern/Western Indo-European group on the other.

For easier reference, we reproduce Berger's table of the phonological system of $\mathrm{Hz} \mathrm{Ng}$ Burushaski, which is essentially valid for the Yasin dialect as well (Yasin Burushaski does not have the phoneme c̣h [Tiffou-Pesot 1989: 7-9]):

Table 1. Phonological system of Burushaski (Berger 1998 I:13)

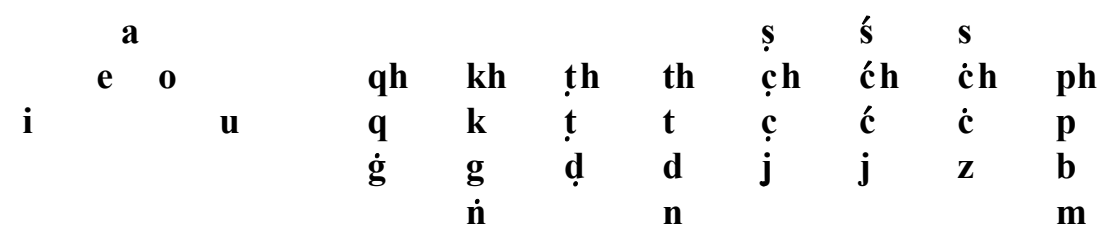

$\begin{array}{llll}\mathbf{l} & \mathbf{h} & \mathbf{l} & \mathbf{r}\end{array}$

Notes:

1. All five vowels can be phonetically long, but for prosodical reasons Berger marks them as double (two component) vowels, in order to mark the position of the stress.

2. Retroflex consonants are marked with an underdot.

3. $\mathbf{w}$ and $\mathbf{y}$ are allophones of $\mathbf{u}$ and $\mathbf{i}$.

4. $\quad \dot{\mathbf{c}}=\mathbf{t s}$ in Lorimer and $\mathbf{c}$ in Tiffou-Pesot (1989).

5. $\dot{\mathbf{n}}=[\mathrm{y}]$ or $[\mathrm{ng}][\mathrm{nk}]$.

2 The grammatical correspondences are outlined in Čašule (2003b: 69-80). We analyse the correlation of the Burushaski numeral system with Indo-European in Čašule (2009).

3 For a detailed appraisal of this evidence, see Alonso de la Fuente (2006). 
6. $\mathbf{y}$ is a retroflex, articulated somewhere between a "r grasséeyé and a $\gamma$ or rather a fricative $\mathbf{r}$ with the tongue in a retroflex position" (Morgenstierne 1945: 68-9).

We summarise below the established phonological correspondences between Burushaski and Indo-European (for the exemplification, analysis, and the internal variation, refer to Čašule (2003b: 24-42):

Table 2. Summary of Burushaski-Indo-European phonological correspondences.

\begin{tabular}{|c|c|c|c|c|c|}
\hline IE $\mathbf{a}$ & $>$ & Bur a & & & \\
\hline $\mathrm{IE} \mathbf{e}$ & $>$ & Bur Ys e : & $\mathrm{Hz} \mathrm{Ng} \mathbf{i}$ & & \\
\hline IE e (unstr.) & $>$ & Bur a & & & \\
\hline $\mathrm{IE} \overline{\mathbf{e}}$ & $>$ & Bur ée, i & & & \\
\hline IE $\mathbf{0}$ & $>$ & Bur ó & & & \\
\hline IE o (unstr.) & $>$ & Bur a & & & \\
\hline IE $\overline{\mathbf{o}}$ & $>$ & Bur oó, óc & & & \\
\hline $\mathrm{IE} \mathbf{i}$ & $>$ & Bur i & & & \\
\hline \multirow[t]{2}{*}{$\operatorname{IE} \mathbf{u}$} & $>$ & Bur $\mathbf{u}$ & & & \\
\hline & & & $\begin{array}{l}\text { IE } \mathbf{a i}, \mathbf{e i}, \mathbf{o i} ; \mathbf{e u} \\
\text { IE } \mathbf{a u}, \mathbf{o u}\end{array}$ & $\begin{array}{l}> \\
>\end{array}$ & $\begin{array}{l}\text { Bur a } \\
\text { Bur u }\end{array}$ \\
\hline $\begin{array}{l}\text { PIE } \mathbf{h}_{\mathbf{1}^{-}} \\
\text {PIE } \mathbf{h}_{\mathbf{1}} \mathbf{e}^{-} \\
\text {PIE } \mathbf{h}_{1} \mathbf{u} \mathbf{e r -}\end{array}$ & $\begin{array}{l}> \\
> \\
>\end{array}$ & $\begin{array}{l}\text { Bur h } \mathbf{h}^{4} \\
\text { Bur he- } \\
\text { Bur har- }\end{array}$ & -war-: her- & & \\
\hline
\end{tabular}

4 In Čašule (2003b), we provide an in-depth analysis of the Burushaski laryngeals and their direct correspondence with the Indo-European laryngeals. We follow the approach by Adams and the editorial board of Mallory-Adams (1997: 462) where four PIE laryngeals are assumed: $\mathbf{h}_{\mathbf{1}}, \mathbf{h}_{\mathbf{2}}, \mathbf{h}_{\mathbf{3}}$ and $\mathbf{h}_{\mathbf{4}}$. In this set, $\mathbf{h}_{\mathbf{2}}$ and $\mathbf{h}_{\mathbf{4}}$ colour an adjacent ${ }^{*} \mathbf{e}$ to $\mathbf{a}$ and $\mathbf{h}_{\mathbf{3}}$ colours an adjacent ${ }^{*} \mathbf{e}$ to $\mathbf{o}$, and are considered to have been pharyngeal and/or laryngeal continuants (fricatives). The first laryngeal $\mathbf{h}_{\mathbf{1}}$ does not cause colouring and has been assumed to be a glottal stop. Adams uses the symbol $\mathbf{h}_{\mathbf{a}}$ when, because there are no Hittite and Albanian forms, it is impossible to determine whether the laryngeal is $\mathbf{h}_{\mathbf{2}}$ or $\mathbf{h}_{\mathbf{4}}$. A generic $\mathbf{h}_{\mathbf{x}}$ is used when there is evidence for a laryngeal, but its exact nature cannot be determined. Most Indo-Europeanists, if not all, accept the existence of at least one laryngeal confirmed by its attestation in Hittite and other evidence, but the three-laryngeal theory also enjoys wide acceptance, whereas the fourth laryngeal has been more often disputed than not. 


\begin{tabular}{|c|c|c|c|c|}
\hline PIE $\mathbf{h}_{\mathbf{2}^{-}}$ & $>$ & \multicolumn{3}{|l|}{$\begin{array}{l}\text { Bur h- } \\
\text { Bur ha- }\end{array}$} \\
\hline PIE $\mathbf{h}_{\mathbf{2}} \mathbf{e}->\mathbf{h}_{\mathbf{2}} \mathbf{a}-$ & $>$ & Bur ha- & & \\
\hline $\mathrm{PIE} \mathbf{h}_{\mathbf{2}} \mathbf{o u}$ - & $>$ & \multicolumn{3}{|l|}{ Bur hu- } \\
\hline PIE h $\mathbf{h}_{2} \mathbf{u} \mathbf{e}-$ & $>$ & \multicolumn{3}{|l|}{ Bur -we- : -wa- } \\
\hline PIE $\mathbf{h}_{\mathrm{a}^{-}}$ & $>$ & \multicolumn{3}{|l|}{ Bur h- } \\
\hline PIE $\mathbf{h}_{\mathbf{a}} \mathbf{e}->\mathbf{h}_{\mathbf{a}} \mathbf{a}-$ & $>$ & \multicolumn{3}{|l|}{ Bur ha- } \\
\hline PIE $\mathbf{h}_{\mathbf{4}^{-}}$ & $>$ & \multicolumn{3}{|l|}{ Bur h- } \\
\hline $\mathrm{PIE} \mathbf{h}_{\mathbf{4}} \mathbf{e}->\mathbf{h}_{\mathbf{4}} \mathbf{a}-$ & $>$ & \multicolumn{3}{|l|}{ Bur ha- } \\
\hline PIE $\mathbf{h}_{\mathbf{3}^{-}}$ & $>$ & \multicolumn{3}{|l|}{ Bur h- } \\
\hline PIE $\mathbf{h}_{\mathbf{3}} \mathbf{e}->\mathbf{h}_{\mathbf{3}} \mathbf{0}-$ & $>$ & \multicolumn{3}{|l|}{ Bur ho- } \\
\hline PIE $\mathbf{h}_{\mathbf{x}}-$ & $>$ & \multicolumn{3}{|l|}{ Bur h- } \\
\hline $\mathrm{PIE} \mathbf{h}_{\mathbf{1}} / \mathbf{2}_{\mathbf{2}} \mathbf{i}-$ & : & \multicolumn{3}{|l|}{ Bur i- } \\
\hline PIE - eh $\mathbf{1}^{-}$ & $>$ & \multicolumn{3}{|l|}{ Ys -ē- : Hz Ng -ee- : -ii- } \\
\hline PIE $\mathbf{h}_{\mathbf{2}} \mathbf{e h}_{\mathbf{x}}-$ & $>$ & \multicolumn{3}{|l|}{ Bur -aa- } \\
\hline PIE $\mathbf{h}_{3} \mathbf{e h}_{\mathbf{x}}-$ & $>$ & \multicolumn{3}{|c|}{ Bur -oo- } \\
\hline \multirow[t]{9}{*}{ PIE -er/lh 1/2 $^{-}$} & \multirow[t]{9}{*}{$>$} & \multicolumn{3}{|c|}{$\mathrm{Hz} \mathrm{Ng} \mathrm{-ii-r/l} \mathrm{:} \mathrm{-aa-r/l} \mathrm{[Ys:} \mathrm{-aha-r/l]}$} \\
\hline & & IE $\mathbf{l}, \mathbf{m}, \mathbf{n}, \mathbf{r}$ & $>$ & Bur $\mathbf{l}, \mathbf{m}, \mathbf{n}, \mathbf{r}$ \\
\hline & & $\mathrm{IE} \underset{\mathbf{u}}{\mathbf{n}}$ & & Bur -w/-u \\
\hline & & IE $\mathbf{u}-$ & & Bur b- \\
\hline & & IE $\mathbf{y}$ & & Bur $\mathbf{y} / \mathbf{i}$ \\
\hline & & IE $\mathbf{m}_{\mathbf{0}}$ & $>$ & Bur-um, am \\
\hline & & IE $\mathbf{n}$ & $>$ & Bur -un, -an \\
\hline & & $\mathrm{IE} \underset{\mathbf{r}}{\mathbf{r}}$ & $>$ & Bur -ur, -ar \\
\hline & & IE ! & $>$ & Bur -ul, -al \\
\hline IE p- & $>$ & Bur ph-, also b- & & \\
\hline IE -p-, -p & $>$ & Bur -p-, -p & & \\
\hline IE bh & $>$ & Bur b & & \\
\hline IE b & $>$ & Bur b, also m & & \\
\hline $\mathrm{IE} \mathbf{t}$ & $>$ & Bur $\mathbf{t}:$ th : $\mathbf{t}$, also d- & & \\
\hline IE dh- & $>$ & Bur d- & & \\
\hline IE VdhV, -dh & $>$ & Bur -t-, -te-, -t & & \\
\hline IE $\mathbf{d}$ & $>$ & Bur d & & \\
\hline IE k & $>$ & Bur $\mathbf{k}: \mathbf{k h}$, also g- : $\mathbf{g}-$ & & \\
\hline $\mathrm{IE} \mathbf{k}^{\mathbf{w}}$ & $>$ & Bur $\mathbf{k}$ & & \\
\hline IE $\mathbf{k}$ & $>$ & Bur k, kh, also g- : $\dot{\mathbf{g}}-$ & & \\
\hline IE $\mathbf{g}, \mathbf{g h}$ & $>$ & Bur $\mathbf{g}, \dot{\mathbf{g}}$ & & \\
\hline IE $\mathbf{g}^{\mathbf{w}}$ & $>$ & Bur $\mathbf{g}, \dot{\mathbf{g}}$ & & \\
\hline IE $\hat{\mathbf{g}}, \hat{\mathbf{g}} \mathbf{h}-$ & $>$ & Bur $\mathbf{g}, \dot{\mathbf{g}}$ & & \\
\hline
\end{tabular}


$\begin{array}{lll}\text { IE } \mathbf{s} & > & \text { Burs or } \mathbf{s}: \dot{\mathbf{c}}, \dot{\mathbf{c} h} \\ \text { IE } \mathbf{k s} & > & \text { Bur śs }\end{array}$

In this paper we look closely at the Burushaski shepherd vocabulary and analyse the lexical correspondences with Indo-European, particularly outside of Indic and Iranian. We first look at twenty correlations in names of 'small cattle (goats and sheep)' (sections 2.2.1-2.2.4) and at eleven related shepherd terms ('shepherd', 'byre', 'grazing ground', 'wool', 'flute') (section 2.2.5).

So far, all of these terms have been deemed to be autochthonous Burushaski words by Berger and Lorimer and other scholars, with the exception of Bur dágar Ng 'ram', ex. [13], which has been tentatively linked by Berger to Indo-Aryan.

We have labelled the validity of the etymologies, in the sense of original Burushaski words of Indo-European (non-Indo-Iranian) origin, as follows: $\mathrm{C}=$ certain, $\mathrm{VP}=$ very probable, $\mathrm{P}=$ probable, $\mathrm{T}=$ tentative. Although such assessment can be subjective, some of the well known criteria applied are: the systematic character of the phonological correspondences, drawing on internal reconstruction where possible, consistency with the phonological processes, alternations, changes and adaptations typical of Burushaski, minimal to no semantic latitude, specific semantics, antiquity in IE, improbability of borrowing, consistent correlations with particular IE groupings and in other semantic fields, avoidance of "root" etymologies, links involving a derivational cluster (e.g. noun + underlying verb, noun + underlying adjective, several nouns + underlying verb, adjective + underlying noun; noun, adjective + underlying verb etc.), correlation of longer phonological segments, etc.

The sources for the IE material are Gottlieb (1931), Pokorny (1959), Watkins (2000), Mallory-Adams (1997), Mallory-Adams (2006) and Buck (1949). It is important to note that the Burushaski material has already been sifted carefully for Persian, Urdu and IndoAryan loanwords by Berger, Lorimer, Morgenstierne, Zarubin, Edel'man, Klimov, Varma, Tiffou, Buddruss, Tikkanen and other scholars who have studied the language - their findings are conveniently incorporated in Berger (1998). The main source we have 
used for further comparison with Indo-Aryan is Turner $(1966)^{5}$ and with Persian, Steingass (1999) [1892].

In all our etymologies we have excluded all cases where there is a full match (phonological or semantic) with Indo-Aryan. It could well be that in some cases we may be identifying as Sanskritisms the native Burushaski Indo-European vocabulary. Thus, for example, in Berger (1998) there are 45 Burushaski stems not found in the surrounding Indo-Aryan languages which he relates directly to Turner's Old Indian entries, sometimes with no intervening attestations within Indo-Aryan, and with little (or inconsistent) historical change. The phonological rules for Sanskrit borrowings into Burushaski cannot be less systematic just because of the close geographical and historical proximity of the two languages.

\section{Etymological analysis of Burushaski pastoral terms of IE origin}

\subsection{Indo-Aryan and Iranian borrowings}

Burushaski has only a handful of borrowings in words denoting sheep and goats. We list first those already identified: Bur war 'full-grown ram (entire)', rúśe war 'Ovis poli ram' from Wakhi war, wār, Lorimer also points tentatively to Khw werkalu 'ram' (L 371) (B 464); Bur ruś 'Pamir wild sheep, Ovis Poli' < Wakhi riś, Sh ruú ś (B 366); Bur buć 'he-goat, two or three years old, not castrated' (B 60) (L 86) (possibly from Wkh buč registered only by Lorimer); Bur don 'big herd' (also in Sh) < T 6717).

To these we can add Bur baqtá $\mathrm{Hz} \mathrm{Ng}$ 'a type of big sheep', NH 'fat tailed sheep', Ys baxtá, (Sh bakhtá, Khw baxtá) (B 38) from Persian bakhta 'a ram three or four years old; a fat tail' (Steingass 159) and Bur ćhagéni NH 'black goat' (B 95) [and possibly Bur c higír 'goat' (B 76)] < Skt chấgạ- 'he-goat' ( $<$ IE *(s)kē gós- 'sheep, goat', M-A2 140).

5 I am grateful to E. Bashir and C.P. Zoller for their assistance with the IndoAryan material, and to J.A. Alonso de la Fuente and É. Tiffou for their comments, but the responsibility for all shortcomings is mine. 
Bur also has meés 'bag of skin, (...) holds 24-40 lbs of grain' (in Sh kaladu)' which is not found in the surrounding Indo-Aryan or Iranian languages (L 286). Berger (B 286) points to T 10343, i.e., Skt *maiṣya- 'ovine', also T 10334 mēṣá 'ram, sheep; fleece, skin'. It is curious that the meaning of the Burushaski word corresponds closer esp. to Lith maĩ̌s as 'bag', Lett mà iss 'sack' or OSl měxŭ 'sack, skin, fur' (M-A2 140) than to the Indo-Aryan developments - nowhere in Indo-Aryan, according to Turner, do we find the meaning 'sack' or 'bag'. 6

Further borrowings from Indo-Aryan are: Bur uriín 'male young sheep, castrated' (B 457), noted as a loanword from Shina, where we have both ŭ răṇ and ŭriín (< T 2349: OInd uráṇa- 'ram, sheep, young animal') from an IE *urrh $\mathbf{r}_{1} \mathbf{e}$ - 'lamb' (M-A2 140) and Bur Ys bran 'ram' (LYs 50) (BYs 135) possibly from Khw bran 'same'.

\subsection{Burushaski autochthonous pastoral vocabulary of Indo-European} origin

2.2.1. Sheep and goats jointly

The overwhelming majority (80-90\%) of the Burushaski terms denoting 'sheep' or 'goats' can be traced to Indo-European - that is the case with 9 of the noted loanwords from Indo-Aryan or Iranian (Persian) and the 20 autochthonous IE terms outside of the IndoIranian sphere which we discuss in this subsection.

The basic Bur word for 'small cattle, sheep and goats' has a firm Indo-European etymology:

[1] [C] Bur huyés (sg and pl) 'small cattle (i.e., sheep and goats)' (B 209) (L 211) (Will 66: 'a sheep; a goat; a flock'), in Ys also: huí s (T-P 140). We should note the difference between Burushaski and neighbouring Shina ēi 'sheep' and Wakhi yobc 'ewe', which eliminates them as a source of borrowing. Burushaski also has [2] [C]

6 Morgenstierne (1935: XXII-XXIII) indicates that "Burushaski retains here the ś which would have been lost in a modern Shina word, and also a very ancient meaning of the word." 
huy óo 'wool-bearing animal, sheep' (L 208) (B 209) (the latter < *huyyoo with a suffix -yo-, see the discussion in [27]).

There is a direct and remarkable correspondence with IE * $\mathbf{h}_{2} \mathbf{6} \mathbf{u} \mathbf{i s}^{7}$

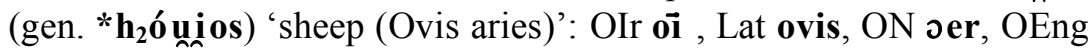
èowu, OHG ou ouwi 'sheep', Lith avis, Lett avs, PSl *ovica (e.g. Mcd ovca) < *owi-kā́, Luw hā wa/i-, Lycian xawa, OInd á viḥ, all: 'sheep', (Pali avi 'ram', Shina ēi 'sheep', etc.), Arm hoviw 'shepherd', Gk ó(w)is 'sheep', Wakhi yobc 'ewe', TochB eye $\left(<* \mathbf{h}_{2} \mathbf{6}\right.$ ú ề is) 'sheep', pl. awi 'ewes' (M-A 510) (G 461) (IEW 784*ó u्ii-s).

Berger (B 209) cites a form hunyes 'sheep, goats' in Hayward (1871), not registered by anyone else as such in his time or later, which indicates it is most likely an error, especially as the group ny would need to have been preserved in Yasin. It could however be explained by derivation from Indo-European as well, from an IE *hou $\mathbf{h}_{2} \mathbf{0} \mathbf{i}$-no-s, as in Baltic *awinas > Lith ãvinas, Lett avins, à uns, OPruss awins and OSl ovi nŭ all: 'ram' (Vasmer III:113, "from an old Indo-European augmentative") and as adjective in Latin ovinus 'ovine'.

The exact semantic and phonological correlation (the preservation of the laryngeal, houi- $>$ hui, -s) with Proto-Indo-European is remarkable in this word attested in eleven of the main groups, which shows once again the "resilience" of basic shepherd vocabulary.

The other basic Burushaski word for 'sheep, goats' jointly can be linked tentatively to Indo-European:

[3] [P] Bur aćás 'sheep and/or goat; small cattle' (L 8) (B 11).

We suggest a possible link with IE * $\mathbf{h}_{\mathbf{a}} \mathbf{e i} \hat{\mathbf{g}} \mathbf{s}-$ 'goat' (M-A 229) (in Wat 1, without a laryngeal: *aî̀-): Alb edh 'kid', Gk aíks '(she-) goat', Arm eyc '(she-) goat', Av izaēnā '(goat) hide'. Perhaps in some way related, and closest to the Burushaski form, note also Phrg aseis 'he-goat' (Haas 1966:158).

In Burushaski we would have the usual changes $\mathbf{a i}>\mathbf{a}$ and $\hat{\mathbf{g}} \mathbf{s}>\mathbf{k s}$ $>\boldsymbol{s}^{\prime}$ and we would have expected a form *aśás or *aśís. It is indicative, however, that we can find examples where we have a ć : 's

7 Some reconstruct the PIE form as * $\mathbf{h}_{3}$ euni- (e.g. Danka 1986: 314) > *houni- both interpretations are possible for Burushaski, where subsequently ou $>\mathbf{u}$. 
variation in Burushaski e.g. maśíś : maćís (B 283) or aśúuś vs Sh aćúus (B 23). Influence from forms like OInd ajá 'he-goat' or Av aza 'he-goat' ( $<$ IE * $\mathbf{h}_{\mathbf{a}} \mathbf{e g} \mathbf{0 s}$ 'he-goat') cannot be excluded entirely. In Burushaski, considering the ending -as, maybe $<\mathrm{IE} * \mathbf{h}_{\mathbf{a}} \mathbf{e} \hat{\mathrm{g}} \mathbf{i} \mathbf{o s}$, as e.g. Lith ožỹ s 'he-goat' (IEW 7). ${ }^{8}$

The next Burushaski word has a firm Indo-European etymology and refers both to 'goatskin' and 'sheepskin':

[4] [C] Bur bat 'goatskin, sheepskin; animal hide; a shape, a form, a likeness' (Will 21) (B 44). Further, Berger derives from *u-bat $>$ Bur -wát t' 'skin, body; person' and wat 'bark, a peel, rind' (B 466) (Will 74). Note also Bur batá 'bald; hornless' which Berger relates to the same stem (compares it with the semantics of 'skinhead') (B 44), where we have an exact phonetic match with the IE form below, with $\mathbf{- a}<-\mathbf{e h}_{\mathbf{2}}$ in the auslaut.

Most likely related, reflecting the $\mathbf{p}: \mathbf{b}$ alternation in IE below, is Bur phatáko Ng 'bald', which Berger (B 327) links with batá 'bald' (B 44).

The Burushaski words correspond directly with IE *baiteh $\mathbf{2}_{2}$ 'goatskin, cloak' (OEng pād 'coat', OHG pfeit 'garment', Goth paida 'tunic, shirt', Gk baítē 'shepherd's or peasant's coat of skins; tent of skins', maybe also Alb petk 'clothes, garment' (IEW 92-3: *baita *paita - considered in Greek possibly from a Thracian source) (M-A 109-110: "may be but need not be a borrowing from a non-IE source").

In the following very complex example the reference is to 'kid' or 'lamb':

8 Starostin (1988: 114), in a tentative list of lexical correspondences between Proto-North Caucasian and PIE, correlates both PIE stems [*haeiĝs- and *haeĝos] with Proto-Adyghian-Kabardian *ačá 'he-goat', Adygh āča, Kab āža 'same', also with East Caucasian and notes Dumézil's (1963: 13) earlier correlation of the Adyghian word with IE. Starostin (1988: 154) is inclined to see here borrowings from Proto-North Caucasian into IE. Burushaski seems to fit well in this analysis - having the stem of PAK *ačá + the IE suffix (?) -s, although the Burushaski word could have developed independently and directly from PIE.

9 A hyphen preceding a word indicates that it is used only with pronominal prefixes. 
[5] [C] súmphalikis, with -ph- in $\mathrm{L}$ and $\mathrm{B}$, in $\mathrm{L}$ also súm(p)falikis, but with -p- according to the forms given by $\mathrm{NH}$ : súmpal, sú malkis , súmapalikiṣ '( $\mathrm{L}$ very) young female kid or $\mathrm{lamb}^{10}$, (L 318, also 'a derogatory term for effeminate man') (B 385). Berger derives it from sum 'female animal' (B 384) + the second component that does not occur independently. [We (Čašule 2003b: 31 and 2009) have traced sum 'female animal' and sumán 'male animal' together with Bur -isamanum 'first-born (son, daughter, young animal)' (L 47) from IE *sem 'one' with a semantic development as in Slavic, e.g. Russ samec 'the male animal' and samka 'the female animal' (Buck 139-40).]

Burushaski also has śépalkis 'sheep with fine wool' (L 326) (B 394) (Leit śépaliṣ q. in Berger 2008: 19.3) where śe 'wool' [28], and śékis 'woolly' (B 392), also the compound biśképalkiṣ 'woolcarrying, wool-producing animal', $\mathrm{Ng}$ also biśképaliṣ ${ }^{11}$ ( $<$ biśké 'hair [of animals], fur') (L 84) (B 56, in Berger 2008: 19.3, also 'wool') (see under [8-9]). -kis may be the productive suffix deriving adjectives from nouns in Burushaski (B I: 19.6).

The Burushaski stem -p(h)al- (with $\mathbf{e}>\mathbf{a}$ in an unstressed syllable, see B 1:2.5 and below), can be related to IE *pelh $2^{-}$'bear young' (found in the West Central IE area): Alb pjell 'give birth to, produce', pjellë 'child', pelë 'mare', Gk pôlos 'foal', Arm ul 'kid, young of deer or gazelle', Eng foal (M-A2 192). Burushaski would have lost the underlying verb (like Gk, Arm or Eng), yet note that in biśképalkiṣ 'wool-carrying, wool-producing animal' the semantic element of 'bear, produce' comes to the fore. The Burushaski semantics of 'kid' or 'lamb' fits neatly with the other semantic developments. Particularly interesting is the correspondence between Burushaski and Albanian, considering the large number of correlations in shepherd vocabulary between the ancient Balkan languages and Burushaski.

10 The basic Burushaski word for 'lamb' is mamú śi, derived by Berger $<$ mamú 'milk' + 'sé- 'to eat' (L 253) (B 277), clearly an independent innovation.

11 Berger (ibid) indicates that the forms without -k- should be seen as secondary. 
We can analyse sú mphalikis into four components: sum + phal + i + kiṣ : $<*$ sum-pel $\left(\mathbf{h}_{2}\right)$-yo-kirṣ ${ }^{12}$ or rather $<{ }^{*}$ sum-pel( $\left.\mathbf{h}_{2}\right)$-yo + *kirṣ : sum- 'female animal' + -phal- 'young [newborn = 'very young'] animal [kid, lamb] + a suffix -i- possibly from the relational suffix -yo- discussed in [27] [for a change -yo- (unstressed o) $>\mathbf{- y u - ~ > ~}$ i, note Berger's analysis (2008: 19.15) of Bur Ys ćumánikiṣ < *ćulmányu-kiṣ] + -kiṣ < kíṣo 'interjection for driving away sheep and goats' (NH 'sheep' in children's talk) (B 245) < *kírṣo, of IndoEuropean origin, < IE *kēr(s)- 'horned; sheep, ram, etc.' see [10-12].

The semantic structure of the compound noun would thus be 'female' + 'very young, newborn' + 'sheep' (or 'horned small cattle'): lit. 'female animal+very young+of+sheep/goat', i.e., 'very young female lamb or kid'.

The form sú mpal could be a backformation (as per Berger 2008: 19.3), or perhaps proof that the ending -kis is not actually a suffix here, but a noun.

Berger (ibid) considers -kis in these examples to be the Burushaski adjectival, but also nominal suffix (B I: 19.6), which is probable identifying it in our analysis as the final morpheme would not change significantly our etymological analysis.

Berger (2008: 131-2) offers a different etymological solution. He derives -pal- from bélis ( $\mathrm{L}$ also bēlis), Ys béles 'ewe (which has had young)' (B 48) [14], which in turn he derives from a hypothetical adj. *bélkiș and ultimately from bél- 'to put on clothes' (a stem of IE origin in our analysis < IE * un el-, see the discussion in [27]. He doesn't seem to account for the -i- in sú mphalikis or sú mapalikiṣ, and the postulated change - $\mathbf{m b} \mathbf{b}-\mathbf{- m p}$ - is difficult to substantiate.

His appears to be a weak etymology on several accounts: if the original word means 'young female kid or lamb', there would be no need to indicate especially 'female sheep' twice (by using sum-) and in the other compound nouns it refers to 'sheep' in general. The suggested change -kiș > -is would be most unusual, if not impossible. Moreover, the Ys form wél- 'to put on clothes', points to an older form with w- for $\mathrm{Hz}, \mathrm{Ng}$ bél- 'same' (although Berger [2008: 69]

12 For the change rṣ $>\mathbf{s}$ see e.g. the derivation of gaṣ 'price' (B 150) or bas 'bridge' (B 43). 
suggests the Yasin verb may derive $<* \mathbf{u}$-bel-). And while a direct semantic derivation from 'to put on clothes' to 'wool' is common, much less plausible is a direct link from 'to put on clothes' to 'young sheep or kid'.

It may be possible that -pal- and bélis are actually related (see [14]), yet with a change $\mathbf{p}>\mathbf{b}$ rather than $\mathbf{b}>\mathbf{p}$. The semantic derivation is different to Berger's - from a semantics of 'borne' $>$ 'kid' or 'lamb' and 'bearing young' > 'ewe, which has borne young' (similar to the correlation 'foal' and 'mare' in the Albanian examples above). This provides a coherent frame for all the noted examples.

Berger goes on to stipulate that the form Ys beská ret, $\mathrm{Hz} \mathrm{Ng}$ baskárat, Cunn. Leit. "bashkar" "wether, ram (over 2 years old, castrated)' (L 72) (B 42) [8] should be derived from a "highly reduced first component," i.e., traces bes- $<$ *belikiṣ or *belis or *beliṣ which is highly unlikely (we would also expect compensatory lengthening of the preceding vowel), and for such a radical change there are no other examples.

The Burushaski words are not found as such in any of the neighbouring languages, but there are some developments in Shina and Domaaki on the one hand and Balti on the other, that need to be addressed and explained in order to rule out any borrowing.

As for Shina, Lorimer (in personal communication to Turner (noted in T 8125.2) cites Sh pālo 'young animal' > Dom pālo 'same' (not correlating it with Burushaski). These words most certainly would have been noticed and rejected by Berger who makes excellent and very precise use of Turner. They are at odds semantically with the other derivatives in Indo-Aryan: Kal palṓ(i) 'cattle-shed', Bshk palō 'same', Panj pā̄i 'herdsman, shepherd' < OInd (reconstructed) *pāl 'flock' < OInd (also reconstructed) *pấla 'protection', ultimately from OInd pālá 'protector; herdsman', pālaka 'guardian' (T 8125). The meanings 'herdsman, protector, guardian; cattle-shed' as per Turner and (implicitly) Lorimer, are not recorded for Sh, Dom or Khw, and only in Pk pāla 'keeper', Ksh pāl 'shepherd', Ku pālsi 'shepherd'. Note also OInd avipāla 'shepherd' (T 893). The direct contact and the many borrowings between Burushaski and Shina could suggest the Burushaski words above are loanwords from IndoAryan. Yet, as we have indicated in the introduction, close proximity and language contact cannot absolve us of a systematic explanation. 
The problems with considering súmphalikiṣ a Shina loanword into Burushaski are:

1. Semantically, the Shina word does not refer specifically to 'kid' or 'lamb' or 'sheep', but to 'young of animals' (in general). Within Indo-Aryan this meaning is kept only in the two languages, Shina and Domaaki which in their intensive contact with Burushaski have borrowed readily from it. Moreover, the semantic shift in regard to Old Indian or Indo-Aryan is on the borderline of acceptability (a direct semantic derivation of the word for 'young animal' from the word for 'shepherd' seems to us impossible, so too from 'herd'). Within the Indo-Aryan developments above, both Shina and Domaaki stand out as the only ones with a shift to 'young animal' [even in T 8100: pāra 'bringing across' which Turner gives as the ultimate source for OInd pā lá (above) there are no derivatives denoting any kind of small cattle or other animals].

2. Phonologically, when Burushaski borrows Shina (or for that matter Urdu) words with a long vowel, e.g. Sh rajaá ki (T 10694) > Bur rajaá ki (B 362); Sh jáalo (Pers jālah, Khw jālo) > Bur jáalo (B 219); Sh dáado (T 6261) > Bur dáado (B 108); Sh dáar (T 6793) $>$ Bur dáar (B 109), etc., the vowel length is retained, which is not the case with the Burushaski pastoral term above.

If Burushaski had borrowed the stem from Shina, it would have retained the -o in súmpal as well, since according to Berger (B I: 209), it has actually borrowed this suffix from Shina.

In Burushaski words borrowed from Shina, we have not been able to find a change $\mathbf{p}->\mathbf{p h}$-, whereas in the older Indo-European layer this is a regular change (Čašule 2003b: 34).

3. The only available source for the Shina word seems to be Lorimer, i.e., his example comes most probably from the Burushaski speaking or adjacent areas, and a strong argument can be made that it is actually a loanword from Burushaski into Shina and Domaaki.

We should comment further on the Balti (Burushaski's Tibetan neighbouring language) word bal, (Tib bal, also Nep bal) all 'wool' (RYTEDD online - in all examples it means 'wool' and not 'sheep' or 'kid'). It is very difficult, if not impossible, to correlate with it Bur sú mphalikis - where the only basic meaning is 'female kid or lamb' or the compound words with -p(h)al- where a first element meaning 'wool' needs to be added, as in: śépalkiṣ 'sheep with fine wool', 
where śe 'wool', and the compound biśképalkiṣ 'wool-carrying, wool-giving animal' where biśké means 'hair (of animals), fur', as the stem does not refer to 'wool'. If the basic meaning of the second component of these compound nouns were 'wool', there would be no need to mark that twice. Furthermore, the phonological change $\mathbf{m b}>$ $\mathbf{m p ( h )}$ would be highly unusual. Moreover, if there is a link with [14] bélis 'ewe (which has had young)', which is probable, then the discrepancy in the stem vowel cannot be explained. All of this rules out Balti as a source for the Burushaski words as well.

All the adduced evidence in our etymological explanations makes this a firm correspondence.

[6] [VP] Bur du 'kid (up to one year old of either sex)', NH also dú do (L 139) (B 123).

It can be correlated internally with a cluster of Burushaski words which we have derived (Čašule 2003a: 36-37) from IE *dhē(i)- 'to breastfeed' (IEW 242), also with the -l- formant, i.e. $<$ IE * $\mathbf{d h h}_{\mathbf{1}} \mathbf{i l e h}_{\mathrm{a}^{-}}$ 'teat, breast', *dheh 1 lus 'nourishing, suckling' (M-A 82, who consider this form a northwestern and late IE word for 'teat, breast').

The stem is strongly represented in Burushaski and cannot be traced phonologically or semantically to Indic or Iranian: (1) Ys -díl (BYs 142), Hz Ng -ndíl 'breast, chest' (L 276) (B 302) (cp. with MIr deil 'teat', OHG tila 'woman's breast', OEng delu 'breast, teat', ON dilkr 'lamb') and further with (2) Ys dúlas 'boy, young lad' (BYs 142), Hz Ng hilés 'boy, lad, youth (unmarried); child, infant' (L 201202) (B 198) (the last form is considered secondary by Berger (2008: 55), derived from the form with d-) (cp. with Lett dêls 'son', Alb djalë 'boy, young man, son' (reconstructed by Cabej 1976 [apud Desnickaja 1984], from OAlb *delās 'a boy'), Lat filius 'son'; (3) Bur díltar 'buttermilk' (: e.g., Alb dhallë 'buttermilk', also Alb dele 'sheep', and further Illyr dalm- 'sheep' (IEW 242), and possibly (4) dú no 'teat of udder' (B 125) (cf. from the same stem OIr denaid 'teat' ( $<*$ dhi-na-ti), dinu 'lamb'). For a discussion of the alternation i:u/_l,r, manifested here, see Berger (2008: 2.10). 
In light of all these examples, it is very likely that Bur du belongs to the same cluster. ${ }^{13}$

\subsubsection{Sheep}

2.2.2.1. Sheep (specific)

[7] [T] Bur śó pan 'sheep's meat' ('Schaffleisch oder Buchweizenteig im Schafmagen gekocht') (also in Sh), śópan bóin 'a shepherd festival' (B 397).

There is a very tentative possibility for comparison with $\mathrm{OHG}$ scāf, Grm Schaf, OEng sceap, Eng sheep, all: 'sheep' under an older hypothesis derived from IE *sqeb- (Gottlieb 1931: 19), i.e., < IE *skẽ b(h)-, also *skã b(h)-, *skob(h)- and *skẽ p-, *skõ p-, *skã p(IEW 930-3) 'base of words with various technical meanings such as 'to cut', 'to scrape', 'to hack' > 'creature' (Wat 77) : Goth gaskapjan 'to create', OHG scaffōn 'form, cause', OEng gesceap 'form, creation', sceppan 'to form', OEng sceafan 'to scrape, pare away', Eng shave, Grmc *sk̄̄pō 'thing cut out', 'container', Gk skaphē

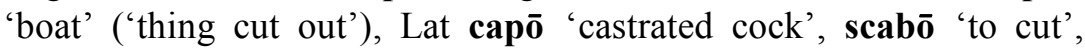
scapula 'shoulder blade', capulā re 'to cut', OSl kopati 'dig', skobli 'scraping knife' etc. (IEW 930-33). Another etymology of Eng sheep etc. would see it as a dissimilated form of IE *(s)kegos- 'sheep, goat', e.g. Skt chấga- 'he-goat' [which is most likely the source of Bur ćhagéni NH 'black goat' (B 95) and possibly of Bur ć higír 'goat' (B 76)], Osset sæy 'she-goat', OEng hēcen 'kid' (M-A2 140).

13 There is a curious parallel between the Burushaski reduplicated form dúdo provided by NH and Illyr deda 'foster mother' which Pokorny (IEW 235) indicates may be from IE *dhē(i)- 'to suckle' rather than from a child word for 'grandparents'. There is a further intriguing correspondence between Bur du 'kid' and Mcd (dial.) dujak 'kid' (-jak is a suffix) (Peev 1988: 41) (the informant explains that it is called dujak from duj- 'to suckle, breastfeed') which is likely to be a coincidence, yet note also Mcd dude 'endearing term (usually) for a small child' (Dimitrovski 187) which could be a diminutive/hypocoristic in -e from a basic form *dudo (as e.g., tate (dem. hyp.) : tato (basic) 'father'). 
In the Burushaski example we have both the meaning of 'sheep' and '(cut up) sheep's meat'. In Burushaski: sk- $>$ 's, and we would have the $\mathbf{0}$-grade of the IE stem.

Another more realistic interpretation could seek a correlation with Pers šubān > Turk çoban 'shepherd', Srb and Croat čoban, MGk tsopá nis, Alb çoban and Rum cioban 'same' (Alinei 2003: 51, who considers the Balkan developments not of Ottoman provenience, but of greater antiquity). The semantics in this second etymology only corresponds partially and we would need to seek a modern Turkic or Iranian source for the Burushaski word.

\subsubsection{Ram}

[8] [C] Bur Ys beská reț, Hz Ng baská rat, Cunn. Leit. "bashkar" 'wether, ram (over 2 years old, castrated)' (L 72) (B 42).

And further, [9] [C] Ys (DC) beś ké, also biśké, Hz Ng biśké 'hair (of animals), fur', biśké șiqá ${ }^{14}$ 'Verbascum thapsus Linn., = kleineblütige Wollblume, an Quellen', and the first component in biś képalkiṣ 'wool-carrying, wool-giving animal' (L 84) (B 56) and perhaps biś qár adj. 'raw, rough wool' (B 56-7). The forms ending in -e would point to a genitive form from *bes-ka or *bis-ka (-e is the Burushaski genitive and ergative ending). The forms with -s- are certainly older, i.e. sk $>$ śk. The derivation of Ys beská ret could be from *bes-ka-r(u)-eti (<'wool-giving').

This is an important direct correspondence with Alb bashkë 'sheep's wool', Rum bască 'same', considered of substratal Paleobalkanic origin by Brâncuṣ (1983: 40-1), who analyses -kë as a suffix. Several etymologies have been put forward for the Albanian and Rumanian words, e.g. 1. From a Thrac *baska, *vaska 'wool', derived with the suffix -ka < IE *ues- 'to clothe'. 2. Russu (apud Brâncuṣ (41) (less likely) < IE *bhasko- 'band, bundle' (e.g., AncMcd bá skioi, Lat fascis 'bundle').

Correlatable to IE *wes- 'to clothe' (Wat 101), Burushaski also has the verb -wáśi- 'put s-thing in or on', (for $y$-sg objects biśá-) 'put on; wear; don (clothing); fix, attach; fit; throw; suspend, hang (etc.)' (Will

14 Compare with the common genitive syntagms like e.g. ćar 'sentry, watchman' : cáre śikáari 'watch tower' (B 69). 
121) (B 56), which can be linked with the first of the proposed Paleobalkanic etymologies, as IE un- > Bur $\mathbf{b}^{-15}$, thus beskáret < *wes-karet and beś ké < *weś-ka $<$ *wes-i-ka.

Lorimer (L 35 and 372) provides forms of the verb with an -estem vowel, and gives both -wásias and -wéśias and the pp. only as n-wéśin (with many of his examples also with $-\overline{\mathbf{e}}-$ as the stem vowel, ${ }^{16}$ which could explain the change $\overline{\mathbf{e}}>\mathbf{i}$ in the form bisá-) which points to an older form with -e- consistently corresponding with IE -e-, thus not derivable from OInd vástē 'to put on clothes' or Av vaste 'same' (IEW 1173). Bur -ś- $<\mathbf{s}+\mathbf{i}$ (for this change, see further Berger 2008: 19.19). For the Burushaski stem ending -i-, the Alb vesh 'to dress', from the same stem, is very indicative, as Orel (1998: 501-

15 For example: IE *uer- 'high raised spot', zero-grade form *ur - (Wat 99) > Bur -ú ri and -ú riṣ 'crest, ridge, peak; prong; fingernail', and Bur buú ri 'crest of hill, peak' (B 66).

IE * un el-7 'turn, wind; round' (IEW 1441-1444) : (from the zero-grade) Bur du-úl- 'wind, become wound up' (B 454), also: Bur bal', -wál- 'fall; find oself in, land in, be beaten; settle down' (B 32), (cp. with OS1 valjati sẹ 'roll, fall clumsily'). And further: Bur bal 'wall' (B 31), (cp. with Lat vallum 'palisade, wall') (IEW 1140) and Bur du-wál- 'fly, fly away', d--wal- 'winnow' (B 463) balás 'bird' (B 33), cp. with OS1 vlajati șe 'to be cast up'.

IE *uel-s 'to tear, pull' (e.g. in PS1 *ob-velkti 'put on clothes') (M-A 567) $>$ Bur bél- : Ys wél- 'put sth on, don, wear' (B 47). (Refer to [27] lú uyo 'tuft of wool, etc.'.)

IE *uer-s 'perceive, watch out for' (Lith vért 'see, look into', OHG gi-war'careful', OEng warian 'beware', Gk horấn 'see' (IEW 1164) > Bur barén-, baré- 'look, look at; look for, search for; look after, look about' (B 40), also d'waran- 'require, be in need of' (B 465).

IE *unod-ōr- 'water' or *ud-ōr- (suffixed zero-grade form) (Wat 95) (or *ud-rō ?) : Bur buḍóo 'rinsing water', Hz also 'water which becomes warm in the sun' (B 61).

IE *ŭ ŏs 'you plural' (Wat 102) or *uoh1- 'you two' > the Yasin doublet for the pronoun for 2 p.pl. wa : ma (T-P 105, 151), $\mathrm{Hz} \mathrm{Ng}$ ma (through an intermediate *ba ?) (no word in Bur begins with wo-, i.e., all Bur words in w(in the anlaut) have wa- in $\mathrm{Hz} \mathrm{Ng}$ (B 462-466) and wa- and we- in Ys).

In total we have identified 25 such correspondences.

16 While Lorimer's phonological analysis was not entirely adequate, we must take into account his perception of the vowel sounds and phonetics. Being able to draw upon the rich system of vowels in English would have helped him describe more precisely the vowels of Burushaski. 
502) derives it from a PAlb *wesja < IE *woséieti (or *weséi eti ?) (with the IE caus. suffix *-éi-), also Goth wasjan 'dress', Hitt wassezzu, Skt vāsáyati (RV) 'clothes' ( $\mathrm{T}$ 11600, in all of IA continued only in Si vasanavā 'clothe, cover' ) (M-A 109). The Bur -i- might otherwise be from the IE *-io- formations (see the discussion in Čašule 2003b: 78), the most important and productive present suffix of late IE, as the Burushaski present stem regularly involves yodation, whereby $\mathbf{s}>$ 's (see e.g., E-K 30; 60-61).

In relation to the suffix *-k(a) posited above, there are indications of an old, no longer productive Burushaski nominal suffix -k(a) (if not a form of the suffix -ko).

We note examples with the same derivational structure, like $\mathrm{Hz} \mathrm{Ng}$ bisqá 'saliva' : Ys mesqé, musqé 'same' (L 83) (B 56), with the b:m alternation, most likely from the zero-grade of IE *meus-, *meug'damp; slimy, slippery, with derivatives referring to various wet or slimy substances' (Wat 55) (IEW 744-5) + the suffix -ka. The bare stem is possibly to be found in Bur -mús 'snot, nasal mucus' (B 296).

For this $-\mathbf{k}(\mathbf{a})$ suffix, perhaps most relevant to the analysis here (with an unreduced suffix -ka ?) is Bur tharká and thará (< ther) 'strip of dirt on the face' (B 438) from Bur ther, Ng therk 'dirty, soiled' (L 351) (B 439) (see Berger 2008: 124). Berger points also to Bur gaśk 'thick rope for tying loads, for swings' (B 149) (L 163) : < gaśóo 'rope' (B 149) < Ys gas 'yarn for spinning' < Bur giśá 'to weave' (all grouped together in Berger 2008: 140); also Bur humá k 'quiver (of arrow)' < hunc 'arrow' (B 205), etc. Further examples we have identified are: tark [23]; also śisk 'lead' (according to Berger (2008: 40) with "unclear -k-"); Ys hesk : Hz Ng hisk 'comb' [< IE *kes- , e.g. Hitt kiske/a 'comb' (IEW 585-586), see under [28] or Ys héśstik 'innermost part of the house, lying outside the portion enclosed by the four main roofposts' (LYs 140) (BYs 151), corresponding directly with IE * $\mathbf{h}_{\mathbf{2}} \mathbf{u}$ es-ti-s 'abode' (IEW 1170) from IE * $\mathbf{h}_{\mathbf{2}} \mathbf{u}$ es'dwell, pass the night, stay' (M-A 171) with the semantics of 'hearth', in Bur $<{ }^{*} \mathbf{h}_{2} \mathbf{n}_{\text {es }}$-ti-k(a). From the same Indo-European stem, Burushaski has the underlying verb d'-was- etc. 'remain, remain over, 
live on, stay behind' (B 462) (in L 140, also d-uesas) (analysed in Čašule 2003b: ex. [16]). ${ }^{17}$

The correspondence with the Paleobalkanic developments is remarkable.

Berger (2008: 132) (see in [5]) derives Ys beská reṭ, $\mathrm{Hz} \mathrm{Ng}$ baská rat from a "highly reduced first component", i.e., traces bes$<*$ belikiṣ, or *belis or *beliṣ which is not plausible. Furthermore, that does not account for the obvious connection with beś ké, biśsé.

His suggestion, however, that the component *-karet can be correlated with karéelo 'ram' [10] is not without merit. In this case we could have had a haplology ${ }^{18} *$ bes-ka-karet > beská ret. See also the tentative discussion in [13].

[10] [C] Bur karéelo 'ram' (also in Sh) (B 242) (L 229: karéelu). -éelo is a Burushaski nom. and adj. suffix: nams 'greed, greediness' > nams-eélo, Ng namsiílo 'greedy', also ćhar 'stone', ćhar-eélo 'climber' (B I: 210), perhaps relatable to IE *-lo-, secondary suffix, forming diminutives, nom. and adj. suffix: Latin -ellus dim. suffix, -ilis adj. suffix, OEng *-ling dim. and nom. suffix (Wat 50).

And further from the same stem: [11] [C] Bur káru 'male ibex' (BYs 157) and [12] [C] krizí and krózo 'small cattle (i.e., sheep and goats)' (BYs 157), kíro NH 'sheep (in children's talk)' (B 245) and ${ }^{2}$ khor 'Schafskörper, dem die Eigenwide herausgenommen sind' (B 256). Note also khar 'a call to a sheep or goat' (B 252), and khirgá 'a call to a sheep' (B 255, who relates the first component khirtentatively to kíro 'sheep'), and further kíṣo ( $<$ * kírșo, for the change $\mathbf{r s}>\mathbf{s}$ in $\mathrm{Hz} \mathrm{Ng}$, see the examples and discussion in Berger 2008: 3.26) 'an interjection for driving away sheep and goats' (NH: 'sheep' in children's talk) (B 245). Under one interpretation, suggested by Berger (2008), the component -kar-et in Ys beskáret, $\mathrm{Hz} \mathrm{Ng}$ baská raț, Cunn. Leit. "bashkar" "wether, ram (over 2 years old, castrated)' (B 42) would also belong to the same derivational cluster (in our analysis < *beska-karet, see [8]).

The wide representation of the stem (with apophony): -kar- : -khar- : khir- : kir- : khor in Burushaski (10 words), argues strongly

17 Note in this example once more the alternation we : wa.

18 For various examples of haplology in Burushaski, see Berger 2008: 6.13. 
in favour of considering Burushaski the original source of these words, some of which were subsequently borrowed into Shina (note further Shina Chilās karấ 'a ram') and maybe in Wkh kar 'sheep with short ears' (q. in Zoller 2005: 103).

There is a direct correspondence with Indo-European derivatives from IE *ker- 'horn' [with its many ablaut grades, as *kr-, *kerā-, *kerā-u-, *kerā-i- ] : *kérho ${ }_{2}$ (s), e.g., Gk kéras 'horn', TochB karse 'stag' [<*‘horned one'] or *kóru 'horn', e.g. Lat cervus 'stag', Lith kárvè 'cow', Rus koróva 'cow', Gk kórudos 'crested lark', Av srva- 'horn; claw, talon' and further ON hrūtr 'ram', Gk kárnos 'sheep', kríos 'ram', OInd śr ṅgam 'horn', Hitt kar(a)war 'horns' (Gottlieb 16) (IEW 574) (G 345-6) (M-A2 137).

Thus, we would have: Bur karéelo $<$ IE *ker-eelo (in Burushaski unstressed e>a), Bur káru < IE *krọ h-u- (or *kerā-u- or *ker-u), and Bur ${ }^{2}$ khor $<$ o-grade *kor-. Bur krózo can be derived from IE *kors- (like Gk Ion kó rsē 'head') > *korz- (with a noted change $\left.\mathbf{s}>\mathbf{z} / \mathbf{r}_{-}\right)^{19}+$ Bur plural morpheme $-\mathbf{0}$ and krizí $<*$ kirzi $<*$ kir(s)-

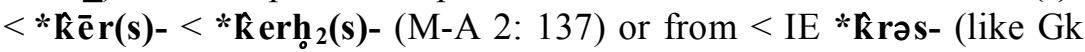
Att kráspedon 'fringe') (IEW 575). Under one interpretation, Bur har 'ox' (B 191) could be ultimately derived from the same IndoEuropean stem, as there are instances where Bur h- seems to derive from k- (as noted by B 381; Morgenstierne 1945: 74; E-K 25, 29; Čašule 2003b: 42) (see also [27]).

Further support for this firm etymology can be found in Bur karóoyo (in Sh karóowo) Ng 'with curved horns' (B 242) ${ }^{20}<\mathrm{IE} \mathrm{kr-}$ iós with the same suffix *-yo- as in [2] huy óo and [27] lú uyo (see the discussion therein). ${ }^{21}$ Alternatively, it may be from IE *kerəwo-s

19 Note e.g. Bur burzóno '(of people) corpulent' (B 64), which we have derived from IE *bhris-, *bhers- 'fast' (sem. in IE > 'sprightly, virilis; defiant, forward; big, a lot' (IEW 143).

20 Note also Ind Koh kı rā 'a ram whose horns are turned inwards' (Zoller 110) which seems to be a loanword from Shina or Burushaski. Zoller (16) estimates that about $10 \%$ of the Indus Kohistani vocabulary consists of borrowings from Burushaski.

21 The basic Burushaski word for 'horn' is ${ }^{1}$ tur $\mathrm{Hz} \mathrm{Ng} \mathrm{Ys} \mathrm{in} \mathrm{Hz} \mathrm{Ng}$ also ${ }^{1}$-Itú $\mathbf{r}$ (L 252, 360) (B 270), which in turn we (Čašule 1998a: 47) have very tentatively 
or * $\mathbf{k} \overline{\mathbf{r}}$ wo-s 'horned'. [In Pokorny (IEW 577), derivations from this precise form are registered only in Lat, Cymr, OPrus, Alb, Lith and S1.] The direct full parallel of the form of the Shina word with IE * Kerəwo-s 'horned' is remarkable. It is possible it may reflect an older Burushaski form.

[13][T] Bur dágar Ng 'ram' (B 128). Berger suggests a tentative connection (which he finds dubious himself) with Skt ḍangara 'cattle, horned cattle' (T 5526?) (everywhere in IA, according to Turner it only means 'cattle'), which is possible, although the Burushaski word does not seem to be found in its Indo-Aryan neighbours, has a very specific semantics and Skt -n g- $>$ Bur $-\mathbf{m}-$ or $-\dot{\mathbf{n}}-$.

It can be compared to derivatives from IE *digh- 'goat' (IEW 222), i.e., from a form of this stem * ${ }^{*}$ deigheh $_{\mathrm{a}^{-}}$, as e.g. Alb dhi 'shegoat' $\left(<*\right.$ deigheh $\left._{\mathbf{a}}-\right)$, and further: Arm tik 'leather skin', OEng ticcen 'kid', ?Gk díza 'she-goat', Grm Ziege 'she-goat', Wkh ti $\gamma$ 'goat call', Ishk dec 'goatskin bag' (M-A 229) and possibly the Phrg gloss attagos 'he-goat' (D-N 95) (N 137). We cannot exclude the possibility that two stems could have merged here.

The final -ar in dágar could be an old suffix (-ru?) in Burushaski, as it is found in a number of other animal names, e.g. thugár 'he-goat' (B 442) (a word that could be historically related), tulpár 'a very quick horse' (L 432), tatár 'tailless rat' (B 445), butár 'male kid (the animal) (under one year old)', c hindár 'bull' (B 65), culdár Ys 'bull' (B 77), ć hiáțar 'young goat' (B 76), ć hiár 'young bull, steer' (L 364), and maybe biśqár adj. 'raw, rough wool' (B 56-7) and bashkar 'wether, ram (over 2 years old, castrated' (L 72) < Ys (DC) beśké, also biśké, $\mathrm{Hz} \mathrm{Ng}$ biśké 'hair (of animals), fur'(see [9-10]).

On the other hand, we could be dealing with a compound word: *dag- 'goat' + *kar- 'horned' (see the discussion under [8] beská ret and [10] karéelo).

related to IE *tauro- 'bull' (Wat 89) < 'the strong, sturdy, big, [solid] (animal)' (Gottlieb 22), or rather: 'horned' (?). 


\subsubsection{Female sheep, ewe}

[14][VP] Bur bélis ( $\mathrm{L}$ also bēlis), Ys béles 'ewe (which has had young)' (L 75) (B 48).

Considering the m:b alternation in Burushaski (B I: 82) (for numerous examples see Čašule 2003b: 28), we could correlate this shepherd term with IE *(s)mēlo- 'small animal', e.g. Arm mal 'sheep', Gk mễ lon 'sheep and goats' (Wat 80). In M-A2 (142) the stem is given as *(s)meh $\mathbf{h}_{\mathbf{1}} \mathbf{l}$ ' 'small animal' with further examples: OIr mil '(small) animal)', Ukr mal 'small cattle (as collective stock)' (Gottlieb 18), ON smale 'small cattle', NDutch maal 'young cow', Eng small, OS1 malŭ 'small' - with a West-Central distribution in IE.

Another etymological interpretation, assuming $\mathbf{p}>\mathbf{b}^{22}$ (Berger 2008: 3.11) would be to derive it from * pelh $_{2}$ ' 'bear young' (found in the West Central IE area): Alb pjell 'give birth to, produce', pelë 'mare', Gk pô los 'foal', Arm ul 'kid, young of deer or gazelle', Eng foal (M-A2 192) and thus possibly related to [5] súmphalikiṣ etc., 'young female kid or lamb' (refer to the extensive discussion under [5].)

It is significant that we appear to have in this example, and in [15], the IE Nom. sg suffix -is (for further examples and discussion, see Čašule 2003b: 71 and the fifteen names of body parts retaining this IE

22 Other historical examples: Bur badá 'sole of foot; step, pace' (B 29) : OInd padá 'footstep, track, pace', in Ys bayá 'same' < (?) Pkt paya- 'footstep, foot' $<$ IE *ped-, *pod- (nom. root) 'foot' and from IE *ped-, *pod- (verbal root) 'fall, stumble': Ys baḍán -wál- 'fall down on one's back, fall over, faint' (BYs 131) (Wat 62). Even in such examples we find the alternation p:b as Burushaski also has padáay -t- 'kick a stone with the foot' (which Berger links with a ? with badá above) (B 310) (See also [17].)

And further examples of a historical change:

IE * $\operatorname{peh}_{\mathbf{x}}(\mathbf{i})$ - 'misfortune', * pih $_{\mathbf{x}}$ ' 'revile' (e.g. OInd pā mán- 'skin disease', píyati 'insults' (M-A 313). In Burushaski we have Ys bihái, $\mathrm{Hz} \mathrm{Ng}$ biái 'illness, disease' (B 50), where the retention of the laryngeal clearly points to an original Burushaski word.

IE *perk - 'to dig out' (Wat 66) > Bur biráq- 'to dig, to dig anywhere' (B $54)$.

IE *pel(i)s- 'rock; cliff' (Wat 64) > Bur balóoṣ 'a kind of stone' (Will 20). 
suffix in Čašule 2003a). There is another possibility of interpreting it as the IE nominal suffix -es, for which see under [21].

[15][C] Bur meénis 'female sheep over one year old which has not had young' (L 264) (B 285).

There is a very strong probability that it may be related to an ancient European cultural word of very wide diffusion, particularly in the Balkans. Semantically, the Burushaski word is closest and almost identical to Rum mînzare 'female sheep (for milking)' and mînzarar 'shepherd of female (milking) sheep', mînzar 'one year old lamb', mînzat 'calf up to two years old' and Brâncus (97-100) considers it a certain substratal (autochthonous) word in the Balkans. And further: Rum mînz, mîndzu 'foal (up to one year old)', Alb (Tosk) mës, mëzi, (Gheg) mâz 'foal (up to two-three years old)', also mezat 'bullock', Messap Menzanas 'epithet of Jupiter' (to whom the Messapians sacrificed horses), Lat mannus 'small horse' (considered from a Paleobalkanic source in Rum, Alb and Lat), Grm (Bavarian) manz, menz 'sterilis uacca', minzekalb 'iuvenca', Itl manzo 'bullock', manza 'young cow, sterile cow' [ $=$ 'cow that hasn't given birth'], (in Basque mando 'mule'), MIr menn 'kid, young of an animal', MWels myn 'young goat, kid', usually derived from the IE stem *mend-, *mond- 'to suck, to feed young animals' (IEW 729).

In Burushaski we would have *mendis > meénis, with loss of -dand compensatory lengthening of -e-. For the loss of -d- in the group -nd-, consider e.g. Bur há nik which B 189 (not found in the neighbouring IA languages) derives directly from OInd há ndika ( $T$ 14050) or Ys géndes : Hz Ng géniṣ 'gold' (B 175). Both the specific semantics of 'young animal' and 'not having young' are present in Burushaski and it matches directly the Indo-European and especially the Rumanian developments.

\subsubsection{Goat}

\subsubsection{He-goat}

[16][VP] Bur buqhéni NH 'goat with distinctive features on the head' (B 63).

Compare with IE *bhuĝ os 'buck, he-goat': OIr boc, Wels bwch, OEng bucca, Eng buck, OHG bok (Gmc < *bhuĝnó-), Arm buc 'lamb', Av būza 'goat, he-goat', OInd bukka- 'goat, he-goat' (T 
9312) (M-A 229) (Gottlieb 19, also includes Gypsy buzni). It may be an old loanword from Old Indian, yet everywhere in Indo-Aryan the form has -0- , and the word is not found in the surrounding languages. The -ni ending appears to indicate a closer correlation with the Germanic developments. The -qh-, instead of the usual reflex $\dot{\mathbf{g}}$ (also not corresponding to Indo-Aryan -k-), may be due to expressive reasons, although there is a possibility that the older form would have been *bug ni- > *buqhni- > buqhéni $(\dot{\mathrm{g}}>\mathbf{q}(\mathbf{h}) / \mathbf{C})$. The same ending -eni (not found anywhere in T 9312) is also found in ćhagéni $\mathrm{NH}$ 'black goat' (B 95). For the alternation $\mathbf{q}: \dot{\mathbf{g}}$ in intervocalic position see Varma (1941: 141).

[17][C] Bur butár 'male kid (the animal) (under one year old)' (L 90 also būtar) and ġa butár "Krähenzicklein", schwächliches Junges (von Ziege, Steinbock)' [' $\mathbf{g}$ a 'crow'](L 90) (B 65).

We derive it from IE *u uet-ru- ${ }^{23}$ (*un etero) $\left(<{ }^{*}\right.$ uet- 'year', e.g. Gk etos 'year') similar to OEng wether 'wether', Goth wiprus 'one year old lamb', OIcl veðr, OHG widar 'wether' < Grmc *wethruz perhaps 'yearling', with other suffixes: Lat vitulus 'calf, yearling' (Wat 101), OInd vatsá 'year; yearling, calf', Alb vitsh 'calf' (IEW 1175). Note the close, specific semantic correspondence between the Burushaski meaning 'under one year old' and IE 'yearling'. It may derive from a suffixed zero-grade form *ut-ero- or *ut-ru. It could also have been influenced by forms like buć 'he-goat, two or three years old, not castrated' (B 60) (L 86) (possibly from Wkh buč registered by Lorimer), buqhéni $\mathrm{NH}$ 'goat with certain distinctive features on the head' (B 63), buḍ óko '(very young) foal; small horse, pony' (L 86) (B 61), bum 'ibex, markhor' (L 87) (B 62-3), buṣóoṣ o ${ }^{24}$ 'calf' (B 65) or buá (also bujá) 'cow' (B 60) (this last word could be correlated with derivations from an Indo-European onomatopoetic *bu- like ON

23 Starostin (1988:113) gives as an isogloss with the IE words, Proto-East Caucasian *wVtVrV 'child (up to one year old)': Tsakurian vudra 'kid up to one year old', Tsez beduro 'cub', Batzbean bader, Chechen bēr 'child' and possibly within a Nostratic etymology (Illič-Svityč 1967: 337).

24 Bur bușóoṣo, Ys boșó 'calf', can be traced to IE *ự s- (zero-grade of *uners'dampen, wet; beget') esp. to Lith veřšis 'calf', Lett versis 'ox' and Lat verrēs 'boar', Av varəšna- 'male of animal', OInd vṛṣa-, vṛṣan- 'male of animal' (M-A2 204) (Gottlieb 17-18). 
baula 'cow', Russ bykǔ 'bull', Lat būbalus 'buffalo' (Gottlieb 1931: 26).

A very strong indication that we may be dealing with a derivative from *unet-ru- are the following Burushaski forms, where Berger identifies a suffix -átar: as in buátar 'young cow, heifer' < buá 'cow' (L 86) (B 60) or c̀hiáțar 'young goat' (B 76). From a diachronic point of view, these could be compound nouns and the second component, (which clearly means 'young' 'one year old' perhaps as in buṭár above) in these words could in fact be a noun: *bua- + *wet-ru- $>$ *bua- + wat-ur $>$ buáțar. [For $-w-$ in intervocalic position see e.g. altó-áltar 'forty' (B 16) vs L altó wāltar : altú wā ltar : altúā ltar 'forty' (L 3).]

An alternative connection can be sought with IE *pōu- : *pau- : *pū ${ }^{25}$ 'small, little; young (of animals)', esp. with the t-formant: OInd putrá 'son, child', Lat putus, putillus 'boy', pullus 'young, young (of animals)', Osc puklo- 'child', Balt-Sl *putá 'bird', Lith putýtis 'young animal, young bird' (IEW 842-3). Phonetically a correlation is possible with Old Indian, although putrá in T 8265 everywhere in Indo-Aryan only has the meaning of 'son', and the semantics of the Burushaski word is more closely related to the Latin, Slavic and Baltic developments (yet note however Skt pṓta- ${ }^{1}$ 'young of animal or plant', (e.g., H potí 'young female of any animal') (T 8399). The Burushaski word is not found in the surrounding IndoAryan or Iranian languages and has a retroflex $\mathbf{- t}$.

Both changes (and alternations): w- $>$ b- and p- $>$ b- are well attested in Burushaski (see Čašule 2003b: 33, 40; and [9] and [14] in this paper).

\subsubsection{She-goat}

[18][C] Bur Ys hálkit, Hz Ng élgit 'she-goat over one year old, which has not yet borne young' (L 38) (B 138).

It can be derived from IE *el-, *ol- 'red, brown (in names of trees and animals)' (IEW 302-4), in Wat 23, also without a laryngeal, or rather *h $\mathbf{h}_{1}$ elu- 'dull red' (in IE also: 'yellow; white; reddish, golden' 
(M-A 481) with the $\mathbf{k}$-formant (Wat 23: *ol-ki) (in Gottlieb 14: 'deerlike [horned] animal'), as in OHG ëlho 'elk', ON elgr, OEng eolh 'elk', Eng elk < Grmc *algiz 'elk', Russ losì, Cz, Pl los 'stag', Pam rus 'wild mountain sheep' [borrowed into Bur ruś 'Pamir wild sheep, Ovis Poli' possibly through Wakhi (B 366)], also with an -n- suffix, e.g., OCS jelenĭ 'hart', Lith élnis 'deer', OIr elit < *elno-ti-s 'deer', Arm ełn 'hart', OPrus alne 'animal', and from *l-on-bho-s $>$ ON, Goth lamb 'sheep' (IEW 302-4). Some newer etymological interpretations (Adams 1985, apud M-A 177-178) reject the link of the animal name with the colour term, and propose a form ${ }^{*} \mathbf{h}_{\mathbf{x}} \mathbf{l} \mathbf{k}$ éis or * $\mathbf{h}_{\mathbf{x}} \mathbf{\text { }}$ IR is 'elk'.

The derivation of the Burushaski word would be $<$ IE * $\mathbf{h}_{\mathbf{1}} \mathbf{e l - k}-\mathbf{k}-\mathbf{i}-$. It is highly significant that we have the basic colour form in Bur hal 'fox; yellowish, reddish' (B 186) (a $<\mathbf{e}$ in unstressed position, consider the pl. form haljó) (see Čašule 2003b: 46-7). The Hunza and Nager form maintains the e-vocalism after the loss of the laryngeal, and it appears that in Yasin we have a form influenced either by the colour term or by some semantic analogy to Bur halk'- 'to give birth', halkís 'womb', Ys Bur halkís 'pregnant cow' (B 188). This correlation is suggested by Berger (2008: 74), but that in itself does not appear to explain the Hunza and Nager forms, nor the suffix -it, or the change in the position of the stress. The vacillation in assigning a laryngeal to this Indo-European stem is perhaps reflected in the dual dialectal outcomes in Burushaski, with and without a laryngeal.

Another very tentative possibility is to analyse $\mathrm{Hz}, \mathrm{Ng}$ élgit as the primary form, i.e., as a compound word: *el- + *git, where the second component in turn could be correlated with IE *gh(a)id-o- (Watkins 28 , who following Pokorny stipulates that this stem could be possibly related [by metathesis] to *digh- [for which see [14]], Lat haedus, Goth gaits 'goat', OEng gāt 'she-goat', Eng goat [in IEW 409: *ghaid-o 'goat', who also notes Alb qith 'goat', MIr cit 'sheep', ON kid 'young of animals'], Gottlieb (1931: 16).

A conflation of two forms cannot be ruled out.

Burushaski also has [19][P] haldén 'male goat (full grown, and in the case of domestic goats, castrated); a male ibex' (Wil 63). The first component would very likely be related to the examples above and the second could be the Burushaski word dén 'year; age' (B 118) as in jimdén 'any time in the future' (B 227). The semantics would be 
'over one year' $\sim$ 'of age'. [Another etymological interpretation could be $<* \mathbf{h}_{1}$ el-t-en, by metathesis $<$ IE * $\mathbf{h}_{1}$ eln - ti- (?)]

\subsubsection{Young of animals}

The following term is used to refer to young animals in general, including lambs, kids, calves, kittens, chickens etc.

[20] [C] Bur '́sk, NH Bur '-sko, Ys -ís 'young (of animals), young one; also jokingly for children', e.g., (belise) ā lta iskumuts bie 'there are two young ones (lambs)', or buś isk 'kitten' < buś 'cat' (L 316) (B 380). It has the force of a diminutive.

There is a direct connection with IE *-i-sk 'formant of adjectives and noun diminutives' (Illič-Svityč 1976 I: 204, who indicates that the -i- is probably from the i-stems, a continuant from many old root stems), in Wat (36) IE *-isko, compound adj. suffix, forming relative adjectives, denoting origin in Slavic, found also in Germanic and Thracian (for the latter, see Illyes 1988: 212). We have discussed the Burushaski adj. suffix -ki, -ski (e.g., Burú śaski < Burú śin (B 491) and the related -ko-, -kus, -kuś with identical functions in Čašule 2003b: 71-2, also Bur -um adj. and participial suffix < IE -enko, -n ko- (composite suffix with -ko as the second component [Wat 36]). This example shows a full systematic derivational correspondence.

\subsubsection{Other shepherd vocabulary}

\subsubsection{Shepherd}

[21] [VP] huyéltarc 'shepherd, herdsman' (L 211) (LYs 131). B (209) also notes huyéltarċi 'pasture for sheep and goats' and analyses it as [1] huyés + ?, the second component also in $\mathrm{Hz} \mathrm{Ng}$ buáltarce, Ys biétarc 'cowherd' (B 60). For the second component, there doesn't seem to be a veritable internal derivation, although Lorimer (questioned by Berger) points to the verb $\mathrm{Hz} \mathrm{Ng}$ Ys --ltir- 'show, point out, indicate', Ys also "-Itar-, in DC Ys also Ys -Iter- (B 269), which is semantically imprecise, and phonologically we would have expected a form *huyéltirć. The ending $-\dot{\mathbf{c}}$ is a suffix, as in darú $\mathbf{c}$ 'hunter' < darú 'hunting' (B 116) or marú c 'gold washer' < marú 'washing river sand' (B 282), durá ć messenger' (B 125). Berger 
(2008: 144) derives through internal reconstruction the suffix $-\dot{\mathbf{c}}<-$ es (also -is). It most likely corresponds to IE nominal suffix -es in animate stems with possessive semantics, as in IE *kerh $\mathbf{e r}_{\mathbf{1}}$-es'grain' > *Kerh ${ }_{1}$-ếs- '(the one) associated with or possessing grain' (Fortson 2004: 112). Note perhaps further -es, -is in [14] Bur bélis (L also bēlis), Ys béles 'ewe (which has had young)' (L 75) (B 48) if

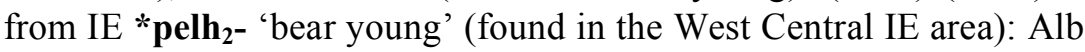
pjell 'give birth to, produce', pelë 'mare', Gk pôlos 'foal', Arm ul 'kid, young of deer or gazelle', Eng foal (M-A2 192), thus: 'bear young' > 'the bearer of young'. The same analysis can be applied to [15] Bur meénis 'female sheep over one year old which has not had young' (L 264) (B 285), which we derived from the IE stem *mend-, *mond- 'to suck, to feed young animals' (IEW 729).

We find a very important close parallel with the Thracian element trair, tral, trâ in personal names like e.g. Trai-bithus, Traii-centus, Aulou-tralis, Auro-tra, Aulu-tra, Muca-tra for which Tomaschek (1980 [1893-1894] II, 2:38f, 102) proposes the meaning 'shepherd, herdsman', from an IE stem *trâ- 'to feed, hold, protect, shield, shelter, look after, care for' (not found as such in Pokorny) and points to Sl trajati 'durare' and Skt Agni-trā as possibilities for comparison.

The stem may be linked derivationally with [24] Bur tark 'byre, hut for animals' (L 346) (B 422), with a basic shared semantics of 'holding, sheltering, enclosing' and can be segmented as *huyés+tra(l)+-íc 'one who shelters, looks after the sheep'.

Another etymological possibility within Indo-European is the stem "“*terh ${ }_{2}$ - oldest form with variant [metathesized] form *treh $\mathbf{2}^{-}$, colored to *trah $\mathbf{2}^{-}$, contracted to *trā-, also zero-grade form * $\operatorname{tr}_{\boldsymbol{0}}(\boldsymbol{\partial})-$ 'to cross over, pass through, overcome' [for derivatives in Bur from this stem that follow typically non-Indo-Iranian forms see Čašule 2003b: 667] : e.g. Skt tirati, tá rati 'he crosses over', trấyati 'protects, shelters' (widespread in IA but without the pastoral element), Irn *thrāya- 'to protect', Lat intrā re 'enter', Hitt tarhzi 'defeats' (Wat 91) (M-A2 395), Av $\operatorname{tar}(\mathbf{v})$ - 'to overcome', $\mathrm{H}$ tārnā 'save' (G 629-30). It is the current preferred etymology also for Sl trajati 'endure, last; wait' mentioned by Tomaschek above, which some (G 634-5) link further with PSl *těrjati 'drive', e.g. Mcd tera 'to drive (out) (esp. cattle, small and big); to force, make; to chase, pursue', Srb terati, Croat tjerati (without Baltic parallels). 
Overall, the correlation and connection with Thracian and with [23] tark 'byre for animals' with a Paleobalkanic etymology, appears to be the most promising one.

[22] [P] Bur dá $\mathbf{k}^{1}$ 'driving animals', dák étas 'drive an animal; follow up tracks', dák ótas hír 'shepherd' (lit. "driving animals man") (L 108) (Will 46). Berger (B 128) unjustifiably gives it together with dák $\mathbf{k}^{2}$ 'to hammer; smithery; sharpening tools', ḍakáalo 'blacksmith' (which only and specifically means 'to hammer'), whereas Lorimer and Willson correctly give the two forms as homonyms. Zoller (220) gives for Indus Kohistani ḍag ghố 'to drive (cattle)'. First word no separate meaning, with parallels only in WPah, where it means 'head of cattle', and points to T 5524a, which has the meaning 'cattle', and not 'driving animals'.

Can be compared with IE *deik-, *deî́ - 'to show, pronounce solemnly, also in derivatives referring to the directing of words or objects', with semantics in IE of 'throw', 'justice, right', 'show, teach', 'sign, mark', 'sample, pattern', 'direction', 'region', 'meadow, pasture', 'rule, cannon, measure' (Wat 14) (M-A 158), e.g., Gk dikéin 'to throw', deiknunai 'to show', OInd dís- 'direction', ON tegr 'strip of land', OHG zeiga 'directions', Av daēsa 'direction, region', OEng fik $\sim$ fik 'meadow, pasture', and from the variant *deî̀- OEng tǣ can 'show, teach', tā(c)en 'sign, mark', Goth taikns 'sign', Lat index 'indicator, forefinger' (< 'pointer') (M-A 159).

In Bur ei $>\mathbf{a}$ and $\mathbf{k}>\mathbf{k}$ (see Čašule 2003b: 31-2, 38). The Burushaski semantics of 'to drive' $=$ 'direct (show) the animals, to follow up tracks (signs)' fits well within the IE developments.

\subsubsection{Byre for animals, goat house, sheep house}

[23] [C] Bur tark 'byre, hut for animals', also tarká ń 'stable', $\mathrm{Ng}$ 'stable for horses' (Berger notes that the latter word has an older pl. ending -án of tark) (B 422) (L 346).

Can be compared conclusively with a Balkano-Carpathian word believed to originate from one of the ancient Balkan languages (Thracian?): Alb thark, cark 'byre for animals', Rum tarc, Arum tarku 'winter byre for sheep; fence around stack' (Neroznak 1978: 207). It is also found in Pl Slk Ukr Hung Mold (Bernštejn 1988: 139), borrowed into Gk as tsárkos. Rasmussen (1999: 648-9) correlates the Albanian word internally with Alb thur 'embrace; fence 
in' and further with Lith tvarkà 'Haltung, Fassung, Ordnung', tvorà 'fence, hedge, borderwall' < Lith tvérti 'embrace, enclose, fence in', ultimately from IE *tun er- ${ }^{2}$, *tur- *tunerə- 'to grab, enclose' (IEW 1101). In Albanian, *tu $>>$ th- $[\theta]$, the intermediate stage, according to Rasmussen (649) being [ts] ("with which one may compare the development of *tu $>\mathbf{s}(\mathbf{s})$ in Greek"), and who goes on to say that "the details and the antiquity of the Albanian word are proved by its appearance as a loanword in Rumanian (...) and Modern Greek (...)".

There are numerous examples of a $\mathbf{t}:$ th alternation in Burushaski, e.g. Hz áltar : $\mathrm{Ng} \mathrm{Hz}$ álthar (B 16), Ys tíśan : Hz Ng thíśan (B 440), tanií : thanií (B 419), Ys tarkón : Hz Ng tharkoón (B 438), tar dél- : thar dél- (B 421), etc. - we have noted seventeen such examples in Berger and a further sixteen examples in Lorimer.

In light of this, [23a][VP] Bur tháark (in Sh thráako) 'walled enclosure (constructed around a shrine, or a saint's grave)' (L 337) (B 435) may well belong here, esp. as Lorimer gives it as thārk in the dictionary entry, but as tārk in the example. We have already noted (Čašule 2004: 84) the possibility that the Phrygian word terkos 'burial plot' from the inscriptions (Orel 1997: 461, without etymology) could be correlated with the Burushaski words.

In Burushaski we would have tark $<*$ tua ar-k(a) $<*$ tuner-k(a) (note the variation ue : una , as in [15]), and $\mathbf{t}(\mathbf{h})$ áark $<*$ tu $_{\text {erh }}$-ka (with the lengthening caused by the lost laryngeal). For the suffix *-k(a) see [8] and [9].

The exact match with a word belonging to the most ancient Balkan layer of shepherd vocabulary is very important.

[24][P] Bur Ys bač 'goat house, sheep house' (LYs 398).

There is a close correspondence with a Balkan word considered of ancient substratal autochthonous origin and with Carpathian distribution (Neroznak 1978: 204, Alinei 2003: 51): Rum, Megrum baci 'older shepherd, cheese-maker', Arum baciu, bagiu, Alb baç 'same', Mcd bač 'shepherd in charge of a summer mountain pasture', bačilo 'pen, enclosure in the mountains where milking is done and cheese made', also Srb and Croat bač'shepherd', bačija 'pen for sheep', Pl bacza 'Tatra mountain shepherd', 'head of the young shepherds', reg. Cz bača 'shepherd', Hung bacs, bacsa, bacsó 'same' (Skok 1974/I: 85). Skok postulates a Thracian origin. 
Even though the correlation with Burushaski involves a slight semantic change, this is an interesting correspondence.

\subsubsection{Grazing ground}

[25][VP] Bur run'alpine pasture, open grazing ground on hills, grassland' (also in Sh) (L 305: Hz ruuń) (B 366) (Will 100).

Can be compared with IE * reuə- 'to open, space', suffixed zerograde form *rū-mo-: OEng, OHG rū m 'space', OProv run 'ship's hold; space' suffixed form *reu(ə)-es : Lat rūs 'open land, the country [countryside, open fields]' (Wat 71), in M-A 534: IE *réuh $\mathbf{h}_{\mathbf{x}}$ es (<* reuh $\mathbf{h}_{\mathbf{x}}$ - 'be open') and further OIr rōi 'field, open land', Av ravah- 'space', Goth rūms 'open space', Toch $A B$ ru- '(be) open', OCSl ravĭnǔ 'level'. Not found in Indo-Aryan.

We note also Bur rat 'smooth, flat, level' (also in Sh) (L 302) (B 364, who gives Balti rat, rad with the same meaning). In Burushaski, if it is not a Tibetan word (and not found in RYTEDD) it could have developed from the stem above $<*$ reu-to, with the semantics as in the Slavic example.

In Bur run, $\mathrm{Hz}$ ruun $<*$ rū - (with the length preserved in $\mathrm{Hz}$ ) + Bur adj. suffix -un (B I: 5.1) which we have derived from the IE composite adj. suffix *-n ko- with the meaning of 'open' (adj.) at the core of the Burushaski word, i.e. a substantivised adjective $=$ 'the open'. It could on the other hand, be a plural form with the pl. ending -n as e.g. badá sg. 'sole; step, pace' : pl. badá ń (for examples and discussion, see Berger 2008: 11.4), leaving the stem as ru-, subsequently with a double plural form (on the Bur double plural, see B I: 3.32), i.e., runá nć.

Another indication that the stem could be ru- is possibly the $\mathrm{Ng} \mathrm{pl}$. ruánć vs $\mathrm{Hz}$ runánć (Berger 2008:57, who apud Anderson 1997: 1035, gives it however as an example of dissimilation of nasals). Only two more examples of a dissimilation $\dot{\mathbf{n}}-\mathbf{n}>\emptyset-\mathbf{n}$, are cited by Berger, and in both cases we cannot exclude the possibility that the $-\dot{\mathbf{n}}$ in the singular is in origin from an adjectival or a plural ending.

[26][VP] Bur ter 'summer grazing ground up in the mountains, mountain pasture (with some cultivation and farming)' [note the specific semantic correspondence with the Rumanian and Latin examples below] [in contrast to [25] runi]; 'in plant names "wild"' (L 
350) (B 425). Note further the Burushaski toponym Báltar 'village near Chalt above the Baltar glacier' which Berger analyses as ? + ter 'ground' (B 489).

There is a possibility of comparison with Lat terra 'earth, land, country, the earth', derived by some etymologists from IE *ter'spread out, extend' and further to OIr, Wels, Bret tír 'land, country' (Tucker 241) (E-M 687-8). The Rumanian țarînă 'field under cultivation' (not found in Albanian) was considered by Russu (apud Illyes 232) to be a Balkan substratal remnant, although Neroznak (1978: 204) proposes a Latin origin for it, i.e. from Lat terrena 'plough field, arable land'. Another etymological analysis links tentatively the Latin word to IE *ters- 'dry': Lat torrere 'dry up, parch', Gk térsomai 'dry up', Skt tṛ̣ s - 'be thirsty', Eng thirst (Buck 17) (G 639) (Wat 91).

In regard to the possible wider Indo-European links in support of the 'spread, extend' proposal we can point to Bur tirkán '(of spilled oil, wound) to spread' (B 427), tará u manas 'to spill over, overflow (of things on a big scale)' (L 338). In connection with the 'dry' hypothesis note Bur tir man' ‘to dry (of woman's hair)' (B 446).

\subsubsection{Wool}

See also the discussion under [9] Ys beś ké, also biś ké, Hz Ng biś ké 'hair (of animals), fur; wool' and the first component in biś képalkis 'wool-carrying, wool-giving animal' (L 84) (B 56) and perhaps also biś qá r adj. 'raw, rough wool' (B 56-57).

[27][VP] Bur lú uy o 'a tuft of wool; impurity in the wool; small balls of scraped wool, lint' (B 271).

It can be correlated with IE * $\operatorname{uol}_{0} \mathbf{h}_{2} \mathbf{n e h}_{\mathbf{a}^{-}}$'wool' (with different enlargements also 'hair; ear of corn; forest') distributed in nine different groups, e.g., Lat lana, Gk lênos, Skt ứrṇā-, OEng wul(I), NE wool, NWels gwlan, Lith vìlna, Mcd volna, Hitt hulana-, Av varənā-, all: 'wool' (M-A2 177-8) (Wat 98). The Indo-European word is considered a likely derivation from IE *u el- 'to tear, pull' (Wat 98) (IEW 1144), *un elh $\mathbf{2}^{-}$(M-A 150) e.g. Lat vellere 'to tear, pull', villus 'shaggy hair, wool', with derivatives in IE meaning 'wound', 'blood', 'fight', 'captured', 'die', etc.

It is very indicative that Burushaski has the verb waálas 'to get lost, to go astray; to be separated from work or family; to die' (Will 
73) (possibly < *u-baálas) (< IE * unelh $\mathbf{2}^{-}$: e $>$aa caused by the laryngeal). Burushaski also has bél-, Ys wél- 'to put s-thing on, to don, to wear' (B 47) $(\mathrm{L} 77,385)$ (Will 22) that could be traced to IE *unel- 'tear' with a semantic development as in PS1 *ob-velkti 'to put on clothes' < *velkti 'to pull, drag' (related stem: IEW 1144-5) (for the semantics also note Lith drapanos 'clothes', Skt drápi 'cloak, mantle' < IE *der- 'tear' (Wat 16). The Burushaski meaning of 'scraped wool' might reveal the underlying meaning of 'tear'.

We would derive Bur lú uy $0<*$ ulı un-yo, with a suffix -yo- which we can correlate with the IE relational adj. suffix *-yo-, also 'of or belonging to' (Wat 103), also *-iijo- (Fortson 120-121) (and retained in huy óo 'wool-bearing animal, sheep' (L 208) (B 209), and further má mayo 'endearing term for 'mother' < má ma, má mo 'mother' (B 277), śóoyo 'a type of vegetable' < Shina śóo (B 397), karóoyo 'with curved horns' (B 242) (see under [10]), etc. In Burushaski we have evidence of a change ny $>$ y: e.g. Ys nyam : $\mathrm{Hz} \mathrm{Ng}$ uyám 'sweet, tasty' (B 460), Ys nya : Hz Ng ya 'bear' (B 467) etc. For the loss of the initial u- in front of -1 note e.g., the doublet Ng ulán- 'can, to be able' : Ys lán- 'same' (B 454) or Hz Ng -úlgiṣ 'nest' : Ys '́lkiṣ 'same' (B 454). u- is a positional variant of w-/_l or C e.g., Ys wélji : $\mathrm{Hz} \mathrm{Ng}$-úlji 'dream' (B 454). A metathesis ul > lu with lengthening cannot be ruled out.

Perhaps related to lúuyo, from the same Indo-European stem above, is Bur iílikis 'ear of corn, just as it appears' (B 211), with *ifrom the pronominal prefix, and with the alternation i:u/_l : *unl-yokis $>*$ i-ul-yo-kis $>$ iílikis (for the change yo $>\mathbf{i}$ in the inlaut see in [5]). The semantic development is the same as in other Indo-European derivatives, e.g. Corn gwels 'grass', Lith váltis 'panicle of oats, of corn', OPrus wolti 'ear of corn', Srb vlat 'same', Ukr volóti 'panicle' (IEW 1139) which strengthens the etymological analysis.

[28] [VP] Bur śe 'wool’ (L 326) (B 393).

A comparison is possible with developments from IE *kes- 'to comb, scratch, itch': MIr cir , Hitt kiss- kisā (i)- 'to comb', kiske/a 'comb', Luw kiš 'to comb', Lith kasá 'braid', OCS kosa 'braid, hair', česati 'to scratch, to comb', and specifically in regard to wool, as Gk ksainō 'scrape, comb [hair or wool], full [cloth]', or flax, as in OEng heordan [pl] 'hards [of flax], tow' (M-A2 233), with differing semantics in OInd kacchū́ 'itching' or kṣurá 'knife, thorny plant' [ > 
Bur as çhur 'big knife' (B 107], NPers šor 'salty' (IEW 585-586) (G 175) (Trubačev 1974, IV: 86).

The Burushaski form would be from an extended zero-grade: ks+ -e(s) - directly correlatable semantically with Gk ksá sma 'crumpled

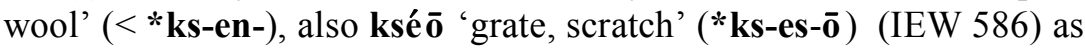
well as with the Slavic and Baltic examples above.

It is important that Burushaski has also Ys hesk, $\mathrm{Hz} \mathrm{Ng}$ hisk 'comb, loom, wrist' (L 204) (B 200) (for the suffix -k(a) see in [8]), which would be a derivation from the e-grade. There are a small number of examples in Burushaski where $\mathbf{h}<\mathbf{k}$ (see the note and references in [10]), which would explain the $\mathbf{h}$ - instead of the prevalent $\mathbf{k}$-. It could be the result of dissimilation.

The following two words belong more to textiles vocabulary, but they are also indirectly related to the pastoral terminology:

[29] [C] philá m 'woollen homespun cloth' (L 290) (B 329) (Will 94).

We can compare it with IE *pel- 'animal skin, hide; cloth; wrap' (Wat 63), in IEW $803 *$ pel-no < IEW 985-986*(s)p(h)el- 'tear off', M-A 268-9: *péln-, B-K 60: *p[h]al- / *p[h]əl- : especially Lat pellis 'animal skin, hide', ON fjall 'skin', OEng fell 'animal skin, hide; pelt', OHG fel 'same', OPrus pleynis 'meninges', Lith plè nẽ 'film (on milk); scab', Lett plẽ ne 'membrane', Russ plená 'felt', Gk pelloráphes 'sewing skins together', Gk spólia 'fine wool plucked from the legs of sheep', and further OEng filmen 'film, membrane, foreskin', Gk pélma 'sole of the foot', Russ plevá 'membrane', also Lat spolium '(animal) skin, hide', $(<*$ (s)pel- 'tear off') (according to M-A, widespread, though not universal, in late PIE).

In Burushaski we would have a derivation of philám $<$ IE *pilman- < IE neut. *pếl-mṇ-, as in Ys hasú man 'star' < há as 'glowing ambers', há numan 'alone' < han 'one' + -man, or hoóm 'sign, omen' (short form of the suffix) < IE * $\left(\mathbf{h}_{2}\right) \mathbf{o} \mathbf{h}_{\mathbf{3}^{-}}$'believe' $>$Lat $\mathbf{\mathbf { o }}$ men 'sign, omen' (for a discussion of the continuants of the IE suffix *men in Burushaski, see Čašule 2003b: 48-9, 58-9). Furthermore, IE p- > Bur ph- (for examples, see Čašule 2003b: 34). Perhaps the second component of the compound noun $\mathrm{Ng}$ gurpáltini, gulpáltin, $\mathrm{Hz}$, Ys gupáltin 'trousers (man's or woman's)' (L 173,4) (B 161) can be correlated here, linked by Berger (2008: 146) to -phált- Hz Ng trs. 'break, break up, hoe, dig a hole, burst in the air' (B 322) (see below). 
From the underlying IE verb *(s)p(h)el- 'to split [break in two], cut off, tear off; board' (IEW 985-7) we have: OInd phálati 'breaks, cuts in two' ( $\mathrm{T}$ 9057), patati 'blows up', Ksh phalun 'to break in two' (and with wide distribution in Indo-Aryan, yet apparently not found in Shina or Khowar) and further Gk sphállo 'trip, knock over, separate, hesitate' etc. For the correlation with Burushaski especially important is the version of this stem with the -t- extension, i.e. $<*($ s)pel-t- : Grm spalten 'to split, to cleave, to chop', Ir alta(i)n, Cymr Ellyn, Bret aotenn all: 'razor', PSl *poltiti- 'to cleave', e.g. Mcd poluti 'break in two' (G 493).

Directly correlatable to this stem is the Burushaski verb --palt- 'to cause to break', -phált- Hz Ng trs. 'break, to break up, to hoe, to dig a hole, to burst in the air' (L 153, also iphalt- 'break a hole in the wall') (B 322).

The extended -t- stem, the absence of a retroflex, the alternation $\mathbf{p}: \mathbf{p h}$ in the Burushaski words and the fact that the verb is not found in the neighbouring Indo-Aryan languages argue strongly against a loanword from Indo-Aryan or Old Indian and reinforce the etymology of this pastoral and textiles term.

[30] [C] Bur gay 'thread in a warp, i.e. for weaving' (B 175).

It shows a remarkable correspondence with IE $* \mathbf{g}^{\mathbf{w}} \mathbf{h e i \partial -},{ }^{*} \mathbf{g}^{\mathbf{w}} \mathbf{h} \mathbf{i}-$ 'sinew, thread' (IEW 489), in M-A (569): * $\mathbf{g}^{\mathbf{w}} \mathbf{h i h}_{\mathbf{x}}\left(-\mathbf{- e h}{ }_{\mathbf{a}}\right)$-, e.g., Lith gijà 'thread (in a warp), skein, hank (of yarn)', Lett dzija 'thread', OSl žila 'sinew', Wels giau (pl.) 'nerves, sinew', Lat filum 'thread', Arm jil 'cord' etc. (not found in Indic or Iranian). The Bur word is semantically precise and specific (identical to Lithuanian), whereas phonetically it could be derived $<{ }^{*} \mathbf{g}^{\mathrm{w}}$ heiə- (ei $>$ a with the laryngeal $>\mathbf{y}$ or $\mathbf{y}$ in intervocalic position, as e.g., in Bur gíy - 'go into, enter' (B 155) < IE *ghē ho $\mathbf{1}^{-}$'let go; go' (Wat 28), or in Bur -yáanis 'so much' (B 468) explained by B < han 'one' (< IE * $\mathbf{h}_{\mathbf{1}} \mathbf{o i}$-no-s 'one') (see Čašule 2009).

\subsubsection{Flute}

[31][P] Bur puréelo 'a (type of) flute' and pururú ro 'flute player' (B 318). Possibly related in the sense 'flute made of reeds', we note Bur phurú u and phurú uy 'reeds, rushes' (L 294) (B 337, who does not make that correlation). For the alternation $\mathbf{l}: \mathbf{r}$, see e.g. phulgú uy : phurgúuy 'feather' (B 335) which we have derived from (as a 
compound word) < IE *pleus- 'feather' + *gour 'body hair, lock of hair' (Čašule 2003b: 23). It is possible that the original Burushaski form was * $\mathbf{p}(\mathbf{h})$ uleero.

There is a very interesting parallel with a Balkan substratal word: Rum flúier 'flute', Arum fluér, fuléru, Alb flojére, floére, floér 'flute', a typical pastoral term also found in Ukr flojara, Pl fujara, Slk fujara, Srb and Croat frula, Hung furulya, MGk flogéra, all: 'flute'. There is no firm accepted etymology for this word (Brâncus 1983: 75), although some have derived it from Gk floiárion 'bark of tree', and others from Lat flā re 'to blow', or as an imitative word.

The semantic correspondence with Burushaski is direct and the metathesis of the liquids would be as in the Serbian, Croatian and Hungarian examples, unless Burushaski displays the original form. Bur does not have [f] - in loanwords it is substituted with $\mathbf{p h}$ or $\mathbf{p}$ and there is undoubtedly some kind of assimilation in pururú ro.

\section{Discussion and conclusions}

Shepherd vocabulary is generally a conservative layer in the lexicon of a language. This can be seen throughout the Indo-European languages and especially very clearly in the case of the Balkan languages. If we look at Poghirc's (1969: 327-356) identification of possible old, substratal words (remnants from the ancient Balkan languages) in Albanian and Rumanian (and their number goes from more widely accepted 122, according to Poghirc, to 210 according to Russu [apud Du Nay 1977: 60-1]), 30\% of them belong to shepherd words in sensu stricto, by far the largest compact semantic group, but if related words are added, as pointed out by Du Nay (1977: 71) the number increases to $58 \%$ of all the words originating from the substratum.

We find the same pattern in Burushaski. It is highly significant that only in reference to 'sheep' and 'goats' we have identified 20 autochthonous Burushaski words of non-Indo-Iranian Indo-European origin. If we add to this number the 9 loanwords from Indo-Aryan and Persian (some of which could have coincided or merged with the Burushaski autochthonous vocabulary), we end up with 29 words of Indo-European provenience in this very restricted semantic field. This 
amounts to $90 \%$ of this vocabulary in Burushaski. In addition we have a further 11 words of closely related shepherd terms (and upon closer inspection this number may be larger), which brings the total to 40 .

In many cases, as in [1] Bur huyés Ys also: huís (sg and pl) 'sheep and goats)' and [2]; [3] Bur aćás 'sheep, goat; small cattle'; [10] Bur karéelo 'ram', also [11-12] (with many derivations); ?[13] Bur ḍágar Ng 'ram'; [14] Bur bélis (L also bēlis), Ys béles 'ewe (which has had young)'; [16] Bur buqhéni NH 'goat with certain distinctive features on the head'; [17] Bur butár (also būtar) 'male kid (under one year old)'; [18] Bur Ys hálkit, Hz Ng élgit 'she-goat over one year old, which has not yet borne young'; [22] Bur dá $\mathbf{k}^{\mathbf{1}}$ 'driving animals', dák ótas hír 'shepherd'; [25] Bur run (also ruun)'alpine pasture, open grazing ground on hills'; [27] Bur lú uy o 'a tuft of wool; small balls of scraped wool'; [28] Bur śe 'wool'; [29] philám 'woollen homespun cloth'; and [30] Bur gay 'thread in a warp, i.e. for weaving' we have examples of words of clear Indo-European antiquity, with no semantic latitude and with non-Indo-Iranian phonological traits.

In a few instances, in widely represented stems in Indo-European, we have specific semantic and derivational developments that align Burushaski with some of the IE groups, e.g. in [26] Bur ter 'summer grazing ground up in the mountains, mountain pasture (with some cultivation and farming)', where we find direct semantic correspondence with the Lat, Rum, Wels and Bret derivatives from a widespread IE stem, or under one interpretation with the Paleobalkanic substratum.

In one case: [5] Bur sú mpal, sú malkiṣ, sú mphalikiṣ, súmapalikiṣ 'young female kid or lamb', we find a specific development within Burushaski connected to a stem found in the West Central IE area, whereby Burushaski has several derivations from it.

The most interesting findings are in the direct and specific semantic, derivational and phonological correlations of Burushaski with the ancient Balkan shepherd vocabulary.

Firstly we have a correspondence with an ancient European cultural word, well attested and identified as substratal in the Balkans, with a specific semantic shift to 'female sheep' both in Rumanian and Burushaski (in the rest of Europe it means 'foal', 'bullock', 'young 
cow', 'kid', 'young of animal'): [15] Bur meénis 'female sheep over one year old which has not had young'.

We have further Paleobalkanic correlations in: [4] Bur bat 'goatskin, sheepskin; animal hide; a shape, a form, a likeness', which has an attestation in IE that assures antiquity and considered by some a possible loanword from a non-IE source, or from Thracian. Especially strong and convincing is the specific correlation of [8] Bur Ys beská reț, $\mathrm{Hz} \mathrm{Ng}$ baská rat 'wether, ram (over two years old, castrated)' < [9] Ys beśké, also biśké, $\mathrm{Hz} \mathrm{Ng}$ biśké 'hair (of animals), fur' with a [Thracian?, Ancient Macedonian?] substratum borrowing in Albanian and Rumanian, with Burushaski also having the probable underlying verb. Very strong, direct and specific is the link between [23] Bur tark 'byre, hut for animals' and Albanian and Rumanian substratal words (+Baltic) and also [23a] thá ark 'walled enclosure (constructed around a shrine)' (+Phrygian). There is another Burushaski-Paleobalkanic (and wider Carpathian) correlation in the case of [24] Bur Ys bač 'goat house, sheep house' (LYs 398) and [31] Bur puréelo 'a (type of) flute' (also with Carpathian distribution). In one instance, in the second component of [21] huyéltarc 'shepherd, herdsman' we find a precise correlation with Thracian. Note also the discussion under [6] du 'kid'. ${ }^{26}$ Especially important is the fact that the two attested Phrygian glosses for 'goat': aseis and attagos, correspond closely with Bur aćás 'sheep, goat' [2] and dágar $\mathrm{Ng}$ 'ram' [13]. This means that in 10 [if we include the Phrygian correspondences: 12], out of $31(\sim 30 \%)$ of the Indo-EuropeanBurushaski correspondences we can trace a direct correlation with the Paleobalkanic developments, with very specific and identical semantics and systematic phonological correspondences. Considering Lett vepris 'boar' (with an unexplained v-, derived by some etymologists (G $666)<*$ wep- 'throw, sprinkle (semen)' ( $<* \mathbf{h}_{1}$ wep- ?), Lat aper, OEng eofor, OHG ebur, epur, all 'boar'. A correlation is possible with Bur béepay, also bépay 'yak' (Tib gyeg), Sh bépo (B 48) (retroflex y possibly < *r-io). It is very important that Bur also has biphér n. 'breed, engendering' (B 53-4) which fits directly with the semantics of 'begetting', and provides evidence for a final -r- in Bur béepay. 
the scarcity of Paleobalkanic attestations, this is an outstanding number.

Of course this does not mean that these words are necessarily Thracian ${ }^{27}$ in origin both in the Balkans or in Burushaski, even if their Paleobalkanic correlation appears to be indisputable. Except for [21] and even then with a conjecture, the substratal words are conveniently hypothesised to be Thracian principally because of the ancient spread of Thracian. We have so little preserved from the Paleobalkanic languages that some of these words could be of Phrygian or Ancient Macedonian origin or from languages almost not attested at all, like Paeonian or mostly onomastically attested languages like Illyrian, or maybe even shared by several of these languages.

The presence in Burushaski of a number of shared alternations and changes like betacism $\mathbf{w}>\mathbf{b}$ (as in Ancient Macedonian, Phrygian, see e.g., Georgiev 1981: 129) or w:b (Thracian) see [9]), or voicing of k(as in variant Latin and Greek transliterations of Thracian onomastics, see Čašule 1998: 67-9) or voicing of p- (as perhaps in Thracian, see [4]), ${ }^{28}$ the alternation $\mathbf{m}: \mathbf{b}^{29}$ (as in Thracian names - see e.g. [14]) makes this link even more viable.

In this regard, these findings fit in with our earlier general analysis of other Paleobalkanic-Burushaski correspondences in Čašule (1998: 13-18, 21-36). ${ }^{30}$ Furthermore, as we have shown in detail (Čašule

27 Yet interestingly, Lorimer (L 438) notes Traqhanáatin (B 438) "a dynasty whose headquarters were at Gilgit. The name is derived from Trakhan (...)" who was its ruler. It is very tempting to seek a historical correlation with the Thracian ethnonym, i.e. with Thrãkes or Thrákion éthnos (Katičić 131-132) although it is more likely that this is a more recent regional development.

28 Consider in regard to Thracian consonantism the discussion and examples in Katičić (1976: 143): "The only safe conclusion is that Greek and Latin writers met with difficulties when rendering Thracian stops in their familiar alphabet. This has been explained (...) as a full-fledged consonant shift, (...) as the orthographic representation of stops somewhat different from the Greek one and similar to the articulation of stops in Albanian".

29 "A most characteristic Thracian feature is the alternation of $\mathbf{b}$ and $\mathbf{m}$." (Katičić 1976: 144).

30 There are also a few words of non-Slavic origin in the highly Balkanised Macedonian language, at the centre of the Balkan Sprachbund, possibly substratal, that find a direct parallel with Burushaski, e.g. Mcd bara 'look for, 
2004), there are other specific semantic fields like ritual, myth, burial and onomastics where we find close and numerous correlations of Burushaski with Phrygian, originally a Paleobalkanic language. ${ }^{31}$ In our analysis of names of body parts of Indo-European origin in Burushaski (Čašule 2003a) we also found possible connections with Phrygian in five of these words.

Our analysis of the shepherd vocabulary of Burushaski reveals a language where almost all the numerous words for 'sheep' and 'goats', together with a large number of related terms can be derived from Indo-European, belonging to a community that from antiquity would have been of a markedly pastoral character. It is highly significant that the specific phonological correspondences manifested in this material are consistent with the other $>550$ lexical correspondences we have analysed in our previous work. Together with the large number of systematic grammatical correspondences with IE, crucial in asserting a genetic relationship, this is further proof of the Indo-European (outside of Indic and Iranian) origin of Burushaski. The strong and precise links in the Bur shepherd vocabulary with the ancient Balkan substratal lexis advance the

search for; seek; demand; look after' (RMJ I: 22) : Bur barén-, baré- 'look, look at; look for, search for; look after, look about' (B 40), possibly < IE *wer- ${ }_{4}$ 'perceive, watch out for' (Wat 99) or more tentatively Mcd vrne 'to rain', a unique Macedonian verb most probably of substratal provenience [for the etymology see Čašule 1998b] : Bur war man' 'rain heavily (B 464) < IE *wē-r- 'water, liquid' or IE *wers- 'to rain, drip' (Wat 100) etc. (For other examples, see Čašule 2001: 125-8.)

31 In the wider semantic field of 'domestic animals' note the direct correspondence between the Phrygian gloss mā 'Phrygian call to cattle' (Neroznak 1978: 150), interpreted as an interjection (prominent and specific enough to be recorded by the ancient lexicographers) and the Burushaski interjection má ha 'come! - a call to a horse' (B 275). Interjections of this type are generally culture-specific, even if they have an expressive component (Bashir p.c.)

Note also in reference to 'horse', the discussion (Čašule 2004: 78-79) of the link between the Bur Ys word kabút 'white horse' (T-M 33), and Bur kabulék 'roof-posts' and Phrygian kubela, Thracian *kabūla 'horse', OS1 kobyla 'mare' > kobylǔ ka 'pole for carrying loads', kobylica 'scaffolding, supporting beams etc.', Lat caballus 'horse, gelding, work horse', words which Buck (168) considers of Anatolian or Balkan ethnic origin. 
hypothesis that Burushaski is the descendant of one of the ancient Balkan languages, very probably Phrygian or a language related to it.

\section{Abbreviations of languages and dialects}

Adygh - Adyghian, Alb - Albanian, AncMcd - Ancient Macedonian, Arm - Armenian, Arum - Arumanian, Av - Avestan, Balt - Baltic, Blg - Bulgarian, Bret - Breton, Bshk - Bashkarik, Bur - Burushaski, Celt - Celtic, Corn - Cornish, Croat - Croatian, Cymr - Cymric, $\mathbf{C z}$ - Czech, Dom - Domaaki, Eng - English, Finn - Finnish, Gk Greek, Gk Att - Attic Greek, Gk Ion - Ionian Greek, Goth - Gothic, Grm - German, Grmc - Germanic, H - Hindi, Hitt - Hittite, Hung Hungarian, $\mathbf{H z}$ - Hunza dialect of Burushaski, IA - Indo-Aryan, IE Indo-European, Illyr - Illyrian, Ind - Indian, Ind Koh - Indus Kohistani, Ir - Irish, Irn - Iranian, Itl - Italic, Kab - Kabardian, Kal - Kalasha, Khw - Khowar, Ksh - Kashmiri, Ku - Kumaunī, Lat Latin, Lett - Lettish, Lith - Lithuanian, Mcd - Macedonian, Megrum - Meglenorumanian, MEng - Middle English, Messap Messapian, MGk - Modern Greek, MHG - Middle High German, MIA - Middle Indo-Aryan, MIr - Middle Irish, Mold - Moldavian, Myc - Mycenean Greek, MWels - Middle Welsh, Nep - Nepali, Ng - Nager dialect of Burushaski, NIA - New Indo-Aryan, NPers - New Persian, OCS - Old Church Slavonic, OEng - Old English, OHG Old High German, OInd - Old Indian, ON - Old Norse , OPers Old Persian, OPrus - Old Prussian, OSI - Old Slavic, Osset Ossetian, OSwed - Old Swedish, OWels - Old Welsh, PAK - ProtoAdyghian-Kabardian, PAlb - Proto-Albanian, Panj - Panjābī, Pers Persian, PGrmc - Proto-Germanic, Phrg - Phrygian, PIE - ProtoIndo-European, Pk - Prakrit, PI - Polish, PNC - Proto-North Caucasian, Prov - Provencal, PSI - Proto-Slavic, Rum - Rumanian, Russ - Russian, RV - Rgveda, Sh - Shina, Si - Sinhalese, Skt Sanskrit, SI - Slavic, Slk - Slovak, Srb - Serbian, SSI - South Slavic, Thrac - Thracian, Tib - Tibetan, Toch A, Toch B - Tocharian A, Tocharian B, Turk - Turkish, U - Urdu, Ukr - Ukrainian, Umb Umbrian, Wels - Welsh, WPah - West Pahārịı, Ys - Yasin dialect of Burushaski 


\section{Abbreviations of sources cited}

$\mathbf{B}=$ Berger, Hermann. 1998.

B-K = Bomhard, A. and Kerns, I. C. 1994.

BYs = Berger, Hermann. 1974.

Cunn $=$ Cunnigham, A. 1854.

DC $=$ Tiffou, E., Morin, Y.C. 1989a.

D-N = Diakonoff, I. M. and Neroznak, V. P. 1985.

E-K = Edel'man, D. I. and Klimov, G. A. 1970.

$\mathbf{E}-\mathbf{M}=$ Ernout, A. and Meillet, A. 1959.

$\mathbf{G}=$ Gluhak, Alemko. 1993.

G-I = Gamkrelidze, T.V. and Ivanov, V.V. 1984.

Hay = Hayward, G. W. 1871.

IEW = Pokorny, Julius. 1959.

L = Lorimer, David L.R. 1938.

L I $=$ Lorimer, David L.R. 1935.

Leit $=$ Leitner, G.W. 1889.

LYs = Lorimer, David L.R. 1962.

M-A = Mallory, J.P. and Adams, D.Q. (eds.). 1997.

M-A2 = Mallory, J.P. and Adams, D.Q. 2006.

RMJ = Rečnik na makedonskiot literaturen jazik. (I-III) 1961-1966.

RYTEDD = Ranjung Yeshe Tibetan-English Dharma Dictionary (online).

$\mathbf{T}=$ Turner, Ralph L. 1966.

T-M = Tiffou, Etienne and Morin, Yves Charles. 1989.

T-P $=$ Tiffou, Etienne and Pesot, Jurgen. 1989.

Wat $=$ Watkins, Calvert. 2000.

Will = Willson, Stephen R. 1999.

\section{References}

Adams, D. Q. 1985. Designations of the Cervidae in Proto-IndoEuropean. Journal of Indo-European Studies 13: 269-282. 
Alinei, Mario. 2003. Interdisciplinary and Linguistic Evidence for Palaeolithic Continuity of Indo-European, Uralic and Altaic Populations in Eurasia, with an Excursus on Slavic Ethnogenesis. Quaderni di semantica 26: 1-57. http://www.continuitas.com/ interdisciplinary.pdf, accessed February 16, 2009.

Alonso de la Fuente, José Andrés. 2006. El burušaski, ¿una lengua aislada? Revista Española de Lingüîstica Vol. 35, no. 2: 551-579.

Bashir, Elena. 2000. A Thematic Survey of Burushaski Research. History of Language 6/1: 1-15.

Bednarczuk, L. 1986. Języki indoeuropejskie. Warszawa: Państwowe Wydawnictwo Naukowe.

Beekes, Robert S.P. 1995. Comparative Indo-European Linguistics (An Introduction). Amsterdam/Philadelphia: John Benjamins.

Berger, Hermann. 1974. Das Yasin Burushaski (Werchikwar). Wiesbaden: Otto Harrassowitz.

- 1990. Burushaski. In Encyclopaedia Iranica. Ehsan Yarshater, ed. London and New York: Routledge and Kegan Paul. Vol IV:567-568.

- 1998. Die Burushaski-Sprache von Hunza und Nager. Teil I. Grammatik. Teil II. Texte. Teil III. Wörterbuch. BurushaskiDeutsch; Deutsch-Burushaski. Neuindische Studien 13. Wiesbaden: Harrassowitz Verlag.

- 2008. Beiträge zur historischen Laut- und Formenlehre des Burushaski. Neuindische Studien 15. Wiesbaden: Harrassowitz Verlag.

Bernštejn, S. B., 1988. Obščekarpatskij dialektologičeskij atlas. Prilozi na Oddelenieto za lingvistička i literaturna nauka, MANU. 133-141.

Biddulph, J. 1986 [1880]. Tribes of the Hindoo Koosh. Lahore: Ali Kamran Publishers. (Orig. published: Calcutta: Government Printing Office).

Bomhard, A., Kerns, I. C. 1994. The Nostratic Macrofamily: A Study in Distant Linguistic Relationship. New York: Mouton de Gruyter.

Brâncuș, Gr. 1983. Vocabularul autohton al limbii Române. Bucharest: Editura Științifică și Enciclopedică.

Buck, C. D. 1949. A Dictionary of Selected Synonyms in the Principal Indo-European Languages. Chicago-London: University of Chicago Press. 
Çabej, E. 1976. Studime etimologjike në fushë të shqipes. Studime gjuhësore. I. Prishtinë.

Čašule, Ilija. 1998a. Basic Burushaski Etymologies. (The IndoEuropean and Paleobalkanic Affinities of Burushaski). MunichNewcastle: Lincom Europa.

- 1998b. Za etimologijata na makedonskiot glagol vrne. Prilozi na Oddelenieto za lingvistička i literaturna nauka. XXIII, 1-2: 121-136.

—. 2001. Osnovni burušaski etimologii. Skopje: TRI.

2003a. Burushaski Names of Body Parts of Indo-European Origin. Central Asiatic Journal 47, no. 1: 15-74.

- 2003b. Evidence for the Indo-European Laryngeals in Burushaski and Its Genetic Affiliation with Indo-European. The Journal of Indo-European Studies 31, nos. 1-2: 21-86.

-2004. Burushaski-Phrygian Lexical Correspondences in Ritual, Myth, Burial and Onomastics. Central Asiatic Journal 48, no. 1: $50-104$

- 2009. (in press) Burushaski Numerals of Indo-European Origin. Central Asiatic Journal. 53, no. 2. (22 pp).

Cooper, Gregory R., Trail, Ronald L. 1999. Kalasha Dictionary - with English and Urdu. Islamabad: National Institute of Pakistani Studies, Quaid-i-Azam University/Summer Institute of Linguistics.

Cunningham, A. 1854. Ladak, Physical, Statistical and Historical: With Notes on the Surrounding Country. London [pp. 398-418 a short word list].

Danka, I. R. 1986. Języki anatolijskie. In Bednarczuk: 275-339.

Desnickaja, A.V. 1984. Sravnitel'noe jazykoznanie i istorija jazykov. Leningrad: Nauka.

Diakonoff, I. M. and V. P. Neroznak. 1985. Phrygian. New York: Caravan Books, Delmar.

Dimitrovski, Todor et al. 1987. Rečnik na makedonskata narodna poezija. Vol. 2., Skopje: Institut za makedonski jazik "Krste Misirkov".

Dumézil, G. 1963. Caucasique du Nord-Ouest et parlers scythiques. Annali. Sezione linguistica. Instituto orientale di Napoli. V. Roma.

Du Nay, André. 1977. The Early History of the Roumanian Language. Edward Sapir Monograph Series in Language, Culture and Cognition 3. Lake Bluff: Jupiter Press. 
Edel'man, D. I. 1997. Burušaski jazyk. In: Volodin, A.P. et al. Paleoaziatskie jazyki. Series Jazyki mira : 204-220. Rosiijskaja akademija nauk. Moscow: Indrik.

Edel'man, D. I., Klimov, G. A. 1970. Jazyk burušaski. Moscow: Nauka.

Ernout, A., Meillet, A. 1959. Dictionnaire étymologique de la langue latine. Paris: Librairie Klincksieck.

Fortson IV, Benjamin W. 2004. Indo-European Language and Culture. Oxford: Blackwell Publishing.

Gamkrelidze, T. V., Ivanov, V. V. 1984. Indoevropejskij jazyk $i$ indoevropejci. Tbilisi: Tbilisi State University.

Georgiev, V. 1981. Introduction to the History of the Indo-European Languages. Sofia: Bulgarian Academy of Sciences.

Gluhak, Alemko. 1993. Hrvatski etimološki rječnik. Zagreb: A. Cesarec.

Gottlieb, Eugene. 1931. A Systematic Tabulation of Indo-European Animal Names: With Special Reference to Their Etymology and Semasiology. Language. Vol VII, no. 3: 5-48.

Haas, Otto. 1966. Die Phrygischen Sprachdenkmäler. Sofia: Bulgarian Academy of Sciences.

Hayward, G. W. 1871. Hunza and Nager, and Yassin. Vocabularies. Journal of the Royal Asiatic Society. Vol. XLI, p. $18 \mathrm{ff}$.

Illič-Svityč, V.M. 1967. Materialy k sravnitel'nomu slovarju nostratičeskix jazykov (indoevropejskij, altajskij, ural'skij, dravidijskij, kartvel'skij, semito-xamitskij). Etimologija. [1965]. Moskva.

- 1976. Opyt sravnenija nostratičeskix jazykov. Vol. 2. Moscow.

Illyes, Elemér. 1988. Ethnic Continuity in the Carpatho-Danubian Area. Eastern European Monographs. CCXIIX. New York: Columbia University Press.

Katičić, Radoslav. 1976. Ancient Languages of the Balkans. The Hague: Mouton.

Leitner, G. W. 1889. The Hunza and Nagyr Handbook. Pt. 1. Calcutta. (Grammar and dictionary of the Nagar dialect).

Lorimer. D. L. R. 1935. The Burushaski Language. Vol. 1. Introduction and Grammar with a preface by G. Morgenstierne. Oslo: Instituttet for Sammenlignende Kulturforskning. H. Aschehoug \& Co. 
1938. The Burushaski Language. Vol. 3. Vocabularies and Index. Oslo: Instituttet for Sammenlignende Kulturforskning. H. Aschehoug \& Co.

—. 1962. Werchikwar-English Vocabulary. Oslo: Norwegian Universities Press.

Mallory, J. P. and D. Q. Adams, eds. 1997. Encyclopedia of IndoEuropean Culture. London - Chicago: Fitzroy Dearborn Publishers.

Mallory, J. P. and D. Q. Adams. 2006. The Oxford Introduction to Proto-Indo-European and the Proto-Indo-European World. Oxford: University Press.

Morgenstierne, Georg. 1935. Preface to Lorimer (1935 I: vii-xxx).

- 1945. Notes on Burushaski Phonology. Norsk Tidsskrift for Sprogvidenskap 13: 61-95.

Neroznak, Vladimir. 1978. Paleobalkanskie jazyki. Moscow: Nauka.

Orel, Vladimir. 1997. The Language of Phrygians. New York: Caravan Books, Delmar.

-1998. Albanian Etymological Dictionary. Leiden: Brill.

Peev, Kosta. 1988. Kukuškiot govor. Skopje: Studentski zbor.

Poghirc, Cicerone. 1967. Considérations sur les éléments autochtones de la langue Roumaine. Revue Roumaine de Linguistique. XII: 1936.

1969. Istoria Limbii Române. Vol. 2. Bucharest.

Pokorny, Julius. 1959. Indogermanisches etymologisches Wörterbuch. Bern-Munich.

Ranjung Yeshe Tibetan-English Dharma Dictionary (online). (www.nitharta.org). Nitharta International: Ranjung Yeshe Publications.

Rasmussen, J. E. 1999. Selected Papers on Indo-European Linguistics. Miscellaneous problems in Indo-European languages VII. Copenhagen: Museum Tusculanum Press (esp. 644-656).

Rečnik na makedonskiot literaturen jazik. Vols. I-III. 1961-1966. Skopje: Institut za makedonski jazik.

Russu, Ion I. 1967. Limba traco-dacilor. $2^{\text {nd }}$ edition. Bucharest.

— 1970. Elemente autohtone în limba română. Substratul comun româno- albanez. Bucharest. 
Skok, Petar. 1974. Etimologijski rječnik hrvatskoga ili srpskoga jezika. Vols. I-IV. Zagreb: Jugoslavenska akademija znanosti i umjetnosti.

Starostin, Sergej A. 1988. Indoevropejsko-severnokavkazskie izoglossy. in Drevnij Vostok: Etnokul'turnye svjazi. Ed. Bongard-Levin, G.M. and V. G. Ardzinba. 112-163. Moscow: Nauka.

Steingass, Francis Joseph. 1999 [1892]. A Comprehensive PersianEnglish Dictionary Lahore: Sang-e-Meel Publications. [Orig. published: London: Routledge \& Kegan Paul.]

Szemerényi, O. J. L. 1996. Introduction to Indo-European Linguistics. London: Clarendon Press.

Tiffou, É. 2000. Current Research in Burushaski: A Survey. History of Language [special issue on Burushaski]. Vol. 6, No. 1: 15-20.

Tiffou, É. and Y. C. Morin. 1989. Dictionnaire complèmentaire du Bourouchaski du Yasin. AMI 17. SELAF 304. Paris: Peeters/Selaf.

Tiffou, É, Pesot, J. 1989. Contes du Yasin. (Introduction au bourouchaski du Yasin avec grammaire et dictionnaire analytique). Paris: Peeters/Selaf.

Tomaschek, Wilhelm. 1980. Die Alten Thraker (Eine ethnologische Untersuchung). Vienna: Austrian Academy of Sciences. (Orig. published 1893-1894.)

Trubačev, Oleg. 1974-. Etimologičeskij slovar' slavjanskix jazykov. Moskva: Nauka.

Tucker, T. G. 1931. A Concise Etymological Dictionary of Latin. Halle (Saale): Max Niemeyer Verlag.

Turner, Ralph L. 1966. A Comparative Dictionary of the Indo-Aryan Languages. London: Oxford University Press.

Van Driem, George. 2001. Languages of the Himalayas. Vols. 1-2. Leiden: Brill.

Varma, S. 1941. Studies in Burushaski Dialectology. Journal of the Royal Asiatic Society of Bengal. (Letters) 7: 133-73.

[Vasmer, Max] Fasmer, Maks. 1986-1987. Etimologičeskij slovar' russkogo jazyka. Vols. I-IV. Moskva: Progress.

Walde, Alois and Julius Pokorny. 1927-32. Vergleichendes Wörterbuch der indo-germanischen Sprachen. 3 vols. Berlin: Mouton de Gruyter. 
Watkins, Calvert. 2000. The American Heritage Dictionary of IndoEuropean Roots ( $2^{\text {nd }}$ edition). Boston: Houghton Mifflin.

Willson, Stephen, R. 1999. Basic Burushaski Vocabulary. Studies in Languages of Northern Pakistan, vol. 6. Islamabad: National Institute of Pakistan Studies/Summer Institute of Linguistics.

Zarubin, I. 1927. Veršikskoe narečie kandžutskogo jazyka. Kollegija vostokovedov. Zapiski 2: 275-364.

Zoller, Claus Peter. 2005. A Grammar and Dictionary of Indus Kohistani. Trends in Linguistics. Documentation. 21-1. Berlin: Mouton de Gruyter. 